\title{
Recent changes in north-west Greenland climate documented by NEEM shallow ice core data and simulations, and implications for past-temperature reconstructions
}

\author{
V. Masson-Delmotte ${ }^{1, *}$, H. C. Steen-Larsen ${ }^{1, *}$, P. Ortega ${ }^{1, a}$, D. Swingedouw ${ }^{2}$, T. Popp ${ }^{3}$, B. M. Vinther ${ }^{3}$, H. Oerter ${ }^{4}$, \\ A. E. Sveinbjornsdottir ${ }^{5}$, H. Gudlaugsdottir ${ }^{5}$, J. E. Box ${ }^{6}$, S. Falourd ${ }^{1}$, X. Fettweis ${ }^{7}$, H. Gallée ${ }^{8}$, E. Garnier ${ }^{9}$, V. Gkinis ${ }^{3}$, \\ J. Jouzel ${ }^{1}$, A. Landais ${ }^{1}$, B. Minster ${ }^{1}$, N. Paradis ${ }^{1}$, A. Orsi ${ }^{1}$, C. Risi ${ }^{10}$, M. Werner ${ }^{4}$, and J. W. C. White ${ }^{11}$ \\ ${ }^{1}$ LSCE (UMR CEA-CNRS-UVSQ 8212/IPSL), Gif-sur-Yvette, France \\ ${ }^{2}$ UMR CNRS 5805 EPOC, OASU, Université Bordeaux 1, 33615 Pessac, France \\ ${ }^{3}$ Centre for Ice and Climate, University of Copenhagen, Copenhagen, Denmark \\ ${ }^{4}$ AWI, Helmholtz Centre for Polar and Marine Research, Bremerhaven, Germany \\ ${ }^{5}$ Institute of Earth Sciences, University of Iceland, Reykjavik, Iceland \\ ${ }^{6}$ GEUS, Copenhagen, Denmark \\ ${ }^{7}$ University of Liège, Liège, Belgium \\ ${ }^{8}$ LGGE (UMR 5183 CNRS-UJF), 54 rue Molière, Domaine Universitaire, BP96, 38402 St Martin d'Hères cédex, France \\ ${ }^{9}$ UMR CNRS LIENSs, Université de La Rochelle, La Rochelle, France \\ ${ }^{10}$ LMD, Paris, France \\ ${ }^{11}$ INSTAAR, Boulder, Colorado, USA \\ ${ }^{a}$ now at: LOCEAN, Paris, France \\ ${ }^{*}$ These authors contributed equally to this work.
}

Correspondence to: V. Masson-Delmotte (valerie.masson@1sce.ipsl.fr)

Received: 25 November 2014 - Published in The Cryosphere Discuss.: 29 January 2015

Revised: 17 June 2015 - Accepted: 23 June 2015 - Published: 6 August 2015

\begin{abstract}
Combined records of snow accumulation rate, $\delta^{18} \mathrm{O}$ and deuterium excess were produced from several shallow ice cores and snow pits at NEEM (North Greenland Eemian Ice Drilling), covering the period from 1724 to 2007. They are used to investigate recent climate variability and characterise the isotope-temperature relationship. We find that NEEM records are only weakly affected by inter-annual changes in the North Atlantic Oscillation. Decadal $\delta^{18} \mathrm{O}$ and accumulation variability is related to North Atlantic sea surface temperature and is enhanced at the beginning of the 19th century. No long-term trend is observed in the accumulation record. By contrast, NEEM $\delta^{18} \mathrm{O}$ shows multidecadal increasing trends in the late 19th century and since the 1980s. The strongest annual positive $\delta^{18} \mathrm{O}$ values are recorded at NEEM in 1928 and 2010, while maximum accumulation occurs in 1933. The last decade is the most enriched in $\delta^{18} \mathrm{O}$ (warmest), while the 11-year periods with the strongest de-
\end{abstract}

pletion (coldest) are depicted at NEEM in 1815-1825 and 1836-1846, which are also the driest 11-year periods. The NEEM accumulation and $\delta^{18} \mathrm{O}$ records are strongly correlated with outputs from atmospheric models, nudged to atmospheric reanalyses. Best performance is observed for ERA reanalyses. Gridded temperature reconstructions, instrumental data and model outputs at NEEM are used to estimate the multidecadal accumulation-temperature and $\delta^{18} \mathrm{O}-$ temperature relationships for the strong warming period in 1979-2007. The accumulation sensitivity to temperature is estimated at $11 \pm 2 \%{ }^{\circ} \mathrm{C}^{-1}$ and the $\delta^{18} \mathrm{O}$-temperature slope at $1.1 \pm 0.2 \% 0^{\circ} \mathrm{C}^{-1}$, about twice as large as previously used to estimate last interglacial temperature change from the bottom part of the NEEM deep ice core. 


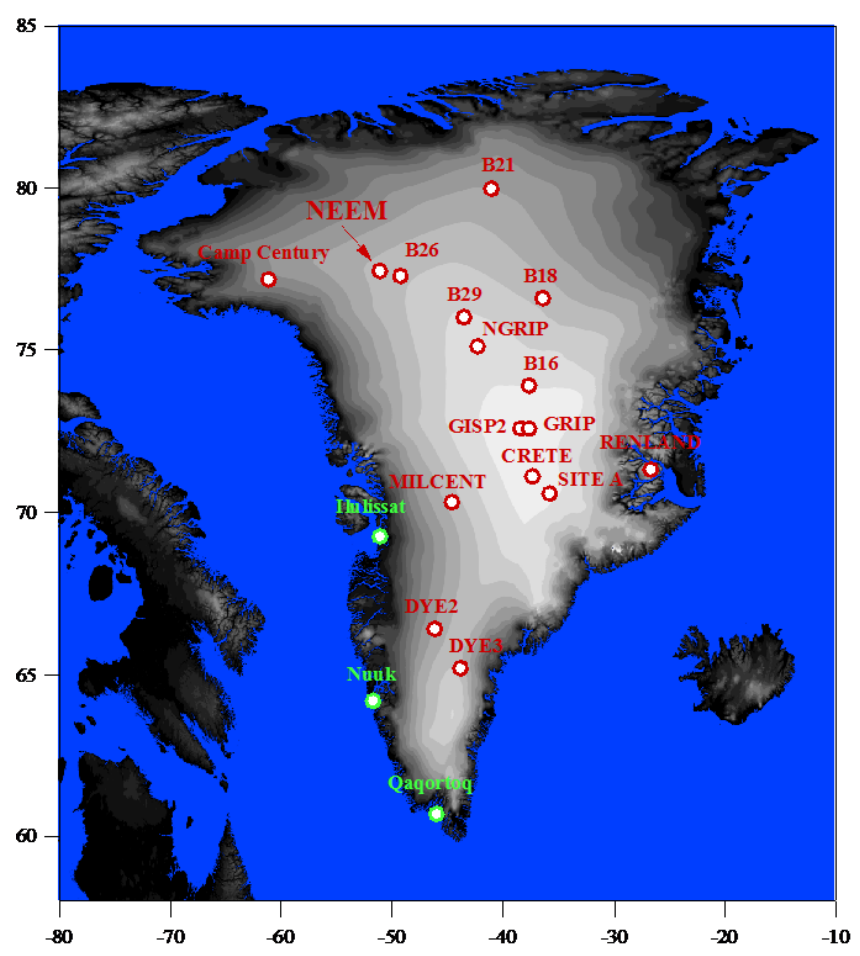

Figure 1. Map of Greenland showing the position of ice core records (red) and meteorological stations (green) used to establish a SW Greenland instrumental temperature record. The grey/white shading indicates elevation (source: NOAA/GLOBE, http://www. ngdc.noaa.gov/mgg/topo/globe.html).

\section{Introduction}

Under the auspices of the International Polar Year and the International Partnership for Ice Core Science, a camp was operated in 2007-2012 at NEEM (North Greenland Eemian Ice Drilling, $77.45^{\circ} \mathrm{N}, 51.06^{\circ} \mathrm{W}, 2450 \mathrm{~m}$ a.s.l.; Fig. 1), in order to retrieve an ice core record spanning the last interglacial period. The deep drilling took place from 2008 to 2012 and delivered a $2540 \mathrm{~m}$ long ice core, providing new information on climate and ice thickness during the last interglacial period (NEEM, 2013). However, large uncertainties remain attached to the interglacial temperature reconstruction, which relies on the interpretation of water-stable isotopes $\left(\delta^{18} \mathrm{O}\right)$ and on the mechanisms of climate variability in north-west Greenland. In this introduction, we briefly review the state of the art with respect to the isotope-temperature relationship in Greenland and at NEEM, and the large-scale drivers of Greenland recent climate variability, before introducing our methodology and the outline of this manuscript.

Studies based on independent palaeothermometry methods or simulations using isotopically enabled atmospheric models show that the isotope-temperature relationship can vary through time and space in Greenland, and be significantly lower than the relationship estimated from a theoretical Rayleigh distillation and from spatial gradients $\left(\sim 0.8 \% 0^{\circ} \mathrm{C}^{-1}\right)$ (Cuffey and Clow, 1997; Masson-Delmotte et al., 2011; Sime et al., 2013). Changes in relationships between the surface and condensation temperature, changes in precipitation seasonality and/or intermittency, and changes in moisture source conditions can indeed cause such deviations (Jouzel et al., 1997; Krinner and Werner, 2003; Persson et al., 2011). During the Holocene, borehole temperature constraints from other Greenland ice cores (Vinther et al., 2009) suggest a coefficient of $0.5 \% 0^{\circ} \mathrm{C}^{-1}$, which was used for the NEEM last interglacial temperature estimate. For warmer than present-day climates, atmospheric models produced a range of coefficients varying from 0.3 to $0.8 \% 0^{\circ} \mathrm{C}^{-1}$ for central Greenland, mostly depending on the patterns of North Atlantic and Arctic SST (sea surface temperature) as well as sea ice changes (Masson-Delmotte et al., 2011; Sime et al., 2013). At NEEM, independent temperature estimates have been obtained during glacial abrupt events, based on gas thermal fractionation in the firn. During the last deglaciation and during several Dansgaard-Oeschger warming events, these data have revealed a higher $\delta^{18} \mathrm{O}$-temperature coefficient $\left(\sim 0.6 \% 0^{\circ} \mathrm{C}^{-1}\right)$ than identified in other Greenland ice cores under glacial conditions (Guillevic et al., 2013; Buizert et al., 2014).

This state of the art has motivated specific studies in order to better document and understand the processes controlling the variability of snow isotopic composition at NEEM for interglacial conditions. For this purpose, and in parallel with deep-drilling operations, the NEEM isotope consortium implemented a surface programme in order to monitor the isotopic composition of surface water vapour, precipitation and surface snow, and retrieve pits and shallow ice cores. Measurements of water vapour isotopic composition performed during four summers (2008, 2010-2012) (SteenLarsen et al., 2011, 2013, 2014) have evidenced a strong relationship between surface vapour $\delta^{18} \mathrm{O}$, local humidity and surface air temperature. The observed vapour $\delta^{18} \mathrm{O}$ is characterised by a linear regression slope of 0.80 to $0.85 \% 0^{\circ} \mathrm{C}^{-1}$. These data also stress the distinct fingerprint of Arctic (subtropical) air masses through high (low) deuterium excess (Steen-Larsen et al., 2013, 2014; Bonne et al., 2015). It is conventionally assumed that the isotopic composition of surface snow reflects a precipitation-weighted climate signal. Yet, observations have also revealed that the isotopic composition of surface snow in the upper $5 \mathrm{~mm}$ varies in-between snowfall events and incorporates changes in surface vapour isotopic composition through surface snow metamorphism (Steen-Larsen et al., 2014). The isotopic exchange between the snow surface and the atmosphere is also consistent with ${ }^{17} \mathrm{O}$-excess measurements (Landais et al., 2012). These data suggest that the NEEM ice cores may record climatic variations more regularly than during snowfall events, at least during summer.

The first NEEM shallow ice core drilled in 2007 during site survey covered years 1960 to 2007 (Steen-Larsen et al., 2011). The data showed a recent $\delta^{18} \mathrm{O}$ increasing trend, 
which, using a slope of $0.8 \% 0^{\circ} \mathrm{C}^{-1}$, was translated to a local warming of $\sim 3^{\circ} \mathrm{C}$. This record showed weak relationships with the closest coastal meteorological station temperature records and no significant correlation with the winter index of the North Atlantic Oscillation (NAO). This is in contrast with the strong NAO imprint identified in south and central Greenland meteorological data and ice cores (Hanna and Cappelen, 2003; Vinther et al., 2003, 2010; Casado et al., 2013; Ortega et al., 2014). Atmospheric circulation models showed that the north-west sector of Greenland encompassing NEEM is characterised by a seasonal maximum of precipitation during summer, which may explain such a weak fingerprint of the winter NAO (Ortega et al., 2014). Finally, this first recent NEEM $\delta^{18} \mathrm{O}$ record revealed a close relationship with the Labrador Sea/Baffin Bay sea ice extent, notable in the coldest year recorded: 1983-1984.

Past changes in the Labrador Sea/Baffin Bay sea ice are related to changes in the North Atlantic Ocean circulation. The principal component of 16 Greenland ice cores' annual $\delta^{18} \mathrm{O}$ (Ortega et al., 2014) has evidenced bi-decadal variability closely linked with the Atlantic Multidecadal Oscillation (AMO) (Enfield et al., 2001; Chylek et al., 2011). Large Pinatubo-like volcanic eruptions act as pacemakers for this bi-decadal variability (Swingedouw et al., 2015). Such multidecadal variability may be recorded particularly strongly at NEEM, as this signal would not be masked by NAO variability. Because the 19th century is marked by repeated large volcanic eruptions, we expect to document their impacts on the regional climate through the NEEM ice core records.

Here, we aim to extend NEEM climatic records back to the 18th century. In order to increase the signal-to-noise ratio known to be low for individual Greenland ice core records (Fisher et al., 1985; White et al., 1997), we combine several individual shallow ice cores. The records of annual accumulation, $\delta^{18} \mathrm{O}$ and deuterium excess are compared with stacked records from other Greenland ice cores (Andersen et al., 2006; Vinther et al., 2010; Ortega et al., 2014); gridded accumulation and surface air temperature reconstructions produced from interpolation of meteorological and ice core data from multiple sites (Box et al., 2009, 2012; Box, 2013); results from different simulations of the regional atmospheric model MAR (Fettweis et al., 2011); and two atmospheric general circulation models including the representation of water-stable isotopes, LMDZiso (Risi et al., 2010) and ECHAM5-wiso (Werner et al., 2011). The ice core data, reconstructions and simulations are described in Sect. 2. The results of the NEEM shallow ice core data are reported and discussed in Sect. 3, where they are compared to other Greenland ice core records, North Atlantic SST and indices of modes of variability. The comparison of NEEM results with reconstructions and simulations is performed in Sect. 4. This model-data comparison will provide an assessment of model performance at NEEM and an evaluation of the $\delta^{18} \mathrm{O}-$ temperature relationship at this site. This section also encompasses a discussion of the implications of the NEEM shal- low ice core data for recent climate change and for pasttemperature reconstructions. This manuscript ends with conclusions and perspectives (Sect. 5).

\section{Material and methods}

\subsection{NEEM shallow ice core data}

Four shallow ice cores (Table 1) were used for this study, with depths ranging from 52.6 to $85.3 \mathrm{~m}$. They were complemented by snow pits to extend water-stable isotope records to the year 2011. Altogether, 10 pit profiles were obtained with a depth resolution of $2.5 \mathrm{~cm}$, covering different subintervals of the period 2003 to 2011. Because density measurements were performed on shallow ice cores and not on pits, accumulation records are only available from the shallow ice cores. Each shallow ice core was cut into $2 \mathrm{~cm}$ samples, stored and melted inside sealed containers, and measurements were performed using mass spectrometers and/or laser instruments at Laboratoire des Sciences du Climat et de l'Environnement (LSCE), France; the Centre for Ice and Climate (CPH), Denmark; the Alfred Wegener Institute, Bremerhaven (AWI), Germany; and the Institute of Earth Sciences (IES), Iceland (Table 1). Inter-calibration was achieved using common laboratory reference waters, and measurements are reported against V-SMOW-SLAP. The accuracy of $\delta^{18} \mathrm{O}$ measurements is respectively $0.05 \%$ (LSCE, mass spectrometry), $0.07 \%$ ( $\mathrm{CPH}$, mass spectrometry) and $0.1 \%$ o (laser instruments, CIC, LSCE, AWI and IES). The accuracy of $\delta \mathrm{D}$ measurements is $0.7 \%$ (AWI, laser measurements; LSCE, mass spectrometry and laser measurements) and $\sim 1 \%$ o (CPH laser measurements, IES laser measurements and mass spectrometry). As a result, the accuracy of deuterium excess calculations (from measurements of $\delta^{18} \mathrm{O}$ and $\delta \mathrm{D}$ on the same samples) as estimated using a quadratic error varies between 0.8 and $1.3 \%$. Altogether, we have performed isotopic measurements on 10500 shallow ice core samples.

The dating of the shallow ice cores was performed by counting of seasonal cycles in $\delta^{18} \mathrm{O}$ and verified using volcanic eruptions identified from electrical conductivity measurements. For an improved identification of individual years, back-diffusion calculation was applied to the $\delta^{18} \mathrm{O}$ records (Johnsen, 1977; Johnsen et al., 2000). During the period 1725-2007, the estimated accumulation rate is $20.3 \pm 3.2 \mathrm{~cm}$ w.e. $\mathrm{yr}^{-1}$ (uncertainty ranges represent interannual SD). At NEEM, the accumulation rate is comparable to that at Summit/GRIP (Greenland Ice Core Project) $\left(21 \mathrm{~cm} \mathrm{yr}^{-1}\right), \sim 15 \%$ higher than at north GRIP (NGRIP) $\left(17.5 \mathrm{~cm} \mathrm{yr}^{-1}\right)$ and $40 \%$ lower than in south Greenland (51 $\mathrm{cm} \mathrm{yr}^{-1}$ at DYE3) (Andersen et al., 2006).

Because the magnitude of seasonal cycles in NEEM waterstable isotopes is strongly affected by diffusion, and therefore 
Table 1. NEEM shallow ice core data: name of the core, depth range (upper to lower depth), time span (start and end years) and laboratory where analyses were performed. Note that the $\delta D$ measurements of 2007 S3 were performed at LSCE only down to 19.65 m (year 1960.5).

\begin{tabular}{lllll}
\hline Ice core name & $2007 \mathrm{~S} 3$ & $2008 \mathrm{~S} 2$ & $2008 \mathrm{~S} 3$ & $2010 \mathrm{~S} 2$ \\
\hline Depth range $(\mathrm{m})$ & $1.15-80.05 \mathrm{~m}$ & $0.025-52.55 \mathrm{~m}$ & $0.875-85.25 \mathrm{~m}$ & $1.275-53.9$ \\
Time span (years CE) & $1739.2-2005.6$ & $1852.5-2008.3$ & $1724.6-2007.4$ & $1852.9-2008.3$ \\
Analyses (lab name) & CIC/LSCE & IES & AWI & CIC \\
Number of samples & 2938 & 2101 & 3376 & 2106 \\
\hline
\end{tabular}

decreases with depth, we decided here to focus on the annual mean signals.

\subsection{Meteorological data and Greenland ice core data}

The NEEM data are compared with long instrumental records of coastal Greenland temperature, established through the combined homogenisation of southwest Greenland meteorological measurements (Vinther et al., 2006) and updated until 2013 (Cappelen and Vinther, 2014). Differences between surface air temperature variability at the surface of the Greenland ice sheet and coastal sites are expected due to effects associated with coastal sea ice changes (for coastal stations) and to the snow and ice surface properties (for the ice sheet), especially for summer temperature (Hanna et al., 2014). For this purpose, the NEEM ice core data are compared to the local grid point outputs from gridded reconstructions of Greenland ice sheet temperature and accumulation, based on a spatial interpolation of weather stations and annual ice core data (Box et al., 2012, 2009; Box, 2013).

The fingerprints of large-scale modes of variability are investigated, using the longest instrumental index of the NAO defined as the standardised difference in sea level pressures between Gibraltar and Iceland (Jones et al., 1997; Vinther et al., 2003), and indices of the AMO based on detrended SST data (Trenberth and Shea, 2006; Enfield et al., 2001) and on proxy evidence (Svendsen et al., 2014). We also explored the relationships with North Atlantic winter and summer weather regimes (NAO+, NAO-, Atlantic Ridge and Scandinavian blocking) as performed for other ice cores (Ortega et al., 2014) and with the Greenland blocking index (Hanna et al., 2013).

The NEEM $\delta^{18} \mathrm{O}$ and accumulation records are also compared with records obtained from other Greenland shallow ice cores (Vinther et al., 2010; Andersen et al., 2006; Ortega et al., 2014). There is heterogeneity in the strength of the signal-to-noise ratio in existing records from ice core sites. Most records were obtained from one single ice core, with a few exceptions where a stacked signal has been extracted from multiple shallow ice cores (GISP2, DYE3). The common signal identified in Greenland ice core $\delta^{18} \mathrm{O}$ (without NEEM) has been extracted using a principal component analysis (Ortega et al., 2014). The same methodology is applied here for accumulation records (Fig. S1 in the Supplement). We hereafter compare the NEEM records with the first prin- cipal components (PC1) of Greenland ice core $\delta^{18} \mathrm{O}$ and accumulation.

\subsection{Atmospheric simulations}

We use outputs from simulations performed with three atmospheric models (MAR, LMDZiso and ECHAM5-wiso), the latter two equipped with the explicit modelling of waterstable isotopes, which means that they simulate the water cycle for each water molecule and account for fractionation processes occurring during phase changes. These simulations are used to assess whether the NEEM signals are explained by changes in large-scale atmospheric circulation, to assess whether models can accurately capture the observed changes at NEEM and to explore the magnitude of NEEM warming and the $\delta^{18} \mathrm{O}$-temperature relationship.

MAR is a regional atmospheric model including processes specific to the ice sheet surface, specifically adjusted to have a realistic representation of Greenland climate, and widely used to investigate changes in Greenland ice sheet mass balance (Fettweis et al., 2011; Fettweis et al., 2013b). Here, we compare version 3.4 of the MAR model nudged against different sets of atmospheric reanalyses: ERA-40 (1958-1979) (Uppala et al., 2005) and ERA-Interim (1979-2014) (Dee et al., 2011), NCEP-NCAR v1 (1948-2013) (Kalnay et al., 1996) NCEP 20CR (1871-2012) (Compo et al., 2011). Hereafter, these different simulations are named MARv3.4-ERA, MARv3.4-NCEP and MARv3.4-20CR. The reanalyses are used to force the MAR model every $6 \mathrm{~h}$ at the lateral boundaries of its integration domain with temperature, humidity, pressure and winds at each vertical MAR level as well as over the ocean (SST and sea ice cover).

LMDZiso is the isotopic version (Risi et al., 2010) of the LMDZ4 atmospheric general circulation model (Hourdin et al., 2006). The model has a warm and dry bias at NEEM (Steen-Larsen et al., 2011, 2013). It is run at $2.5^{\circ} \times 3.75^{\circ}$ resolution, in a nudged simulation, using the Atmospheric Model Intercomparison Project (AMIP) protocol and different large-scale atmospheric circulation constraints (ERA and 20CR). Note that, in this case, the average ensemble of all 20CR reanalyses was used to drive LMDZiso. We will hereafter distinguish the different LMDZiso simulations by naming them LMDZiso-ERA and LMDZiso-20CR. In this configuration, it was shown that LMDZiso-ERA is able to resolve intra-seasonal variations in south Greenland and 
NEEM present-day water vapour isotopic composition variability for $\delta^{18} \mathrm{O}$, but it failed to capture the magnitude of deuterium excess variability especially for Arctic moisture sources (Bonne et al., 2014; Steen-Larsen et al., 2013, 2014).

ECHAM5-wiso is the isotope-enabled version of ECHAM5, which has been shown to have good performance for global, European and Siberian precipitation isotopic composition, against IAEA/GNIP precipitation monthly monitoring data (Werner et al., 2011; Butzin et al., 2014). Sensitivity tests have stressed the dependence of model results and performance on spatial resolution. Simulations used here were performed at a T63L31 spectral resolution, corresponding to a grid size of about $1.9^{\circ}$ by $1.9^{\circ}$ and 31 vertical levels between surface and $10 \mathrm{hPa}$. The simulation spanning the years 1957-2013 is also performed following AMIP guidelines with a nudging technique towards ERA40 reanalyses, which implies relaxation of surface pressure, temperature, divergence and vorticity. This implies a stronger nudging than the one implemented for LMDZiso, which does not take temperature into account. Hereafter, this simulation is named ECHAM5-wiso-ERA. We also briefly discuss the comparison between this T63 simulation and a T106 simulation performed with the same model and nudging method (1980-2011), but using an improved horizontal resolution.

Here, we focus on the comparison between annual mean (or daily-precipitation-weighted) surface air temperature; precipitation; and, for LMDZiso and ECHAM5-wiso only, precipitation-weighted annual mean $\delta^{18} \mathrm{O}$ and deuterium excess. Post-deposition processes, which may alter the surface snow signals (e.g. wind redistribution, snow metamorphism, sublimation etc.), are not taken into account.

In order to perform model-data comparisons on similar time intervals, we focus on the periods 1958-2007 (which encompasses ERA40 simulations) and 1979-2007 (in order to cover the period when satellite data are used in reanalyses). Our comparison ends in 2007 because this is the last year for which the accumulation data are available, and because the NEEM isotopic records of the most recent years are a composite of a different number of snow pit data, with potential inhomogeneities.

\section{Results}

\subsection{NEEM records and signal-to-noise ratio}

The mean core-to-core coefficient of determination $\left(R^{2}\right)$ is respectively $0.31,0.07$ and 0.30 for $\delta^{18} \mathrm{O}$, deuterium excess and accumulation. This leads to respective signal-to-noise ratios of 1.3, 0.4 and 1.2 for these three records. We conclude that our set of four cores is sufficient to extract a robust $\delta^{18} \mathrm{O}$ and accumulation signal but insufficient for deuterium excess, probably due to larger analytical uncertainty, and larger core-to-core variability. Note that the comparison of two deu- terium excess records obtained at a mean temporal resolution of 2 years at GRIP (Hoffmann et al., 2001) showed a lower signal-to-noise ratio ( $R^{2}$ of 0.02 for $\left.1725-1979\right)$. Further investigations of deuterium excess will require improving either the analytical accuracy or the number of ice core records. In the subsequent parts of this manuscript, we will therefore be cautious not to over-interpret this NEEM deuteriumexcess record. Following earlier studies, we have produced a mean record by calculating the average values and displayed the associated inter-core SD (Fig. 2).

For 1958 to 2007 (a period allowing comparison with simulations; see next section), the mean NEEM $\delta^{18} \mathrm{O}$ value is $-33.4 \pm 1.1 \%$. The $\delta^{18} \mathrm{O}$ record displays stable values in the 18th century, followed by a decrease at the beginning of the 19th century, with the most depleted (coldest) decades being in the 1810s and 1830s. This cold phase is followed by a steady increase until the 1870 s. During the 20th century, NEEM $\delta^{18} \mathrm{O}$ displays high values in the 1920 s and a strong increase during the most recent decades $\left(+0.77 \%\right.$ o decade ${ }^{-1}$ in 1979-2007), as already identified from the first shallow ice core (Steen-Larsen et al., 2011). The most enriched (warmest) decade is observed at the beginning of the $21 \mathrm{st}$ century (2000-2011). The highest $\delta^{18} \mathrm{O}$ annual mean value is however encountered in 1928, followed by $2010(-29.9$ and $-30.6 \%$, respectively). The lowest $\delta^{18} \mathrm{O}$ values appear in 1835 and 1983 (-37.0 and $-36.5 \%$ o, respectively). We will further investigate the spatial structure of climatic and isotopic anomalies of these 2 years in Sect. 4.5.2, including a discussion of the corresponding large-scale modes of variability.

The accumulation record appears very similar to the $\delta^{18} \mathrm{O}$ record with respect to multidecadal changes $\left(R^{2}=0.36\right.$ from 11-year smoothed data). It is reported here in centimetres of water equivalent per year. The mean value over 1725-2007 is $20.3 \pm 3.1 \mathrm{~cm} \mathrm{yr}^{-1}$, in perfect agreement with the mean value for the past 3000 years inferred from the NEEM ice core chronology, of $20.3 \pm 0.3 \mathrm{~cm}$ w.e. $\mathrm{yr}^{-1}$ (Rasmussen et al., 2013); in the latter estimate, the uncertainty indicates $1 \sigma$ on the mean value based on Monte Carlo simulations. The accumulation record also depicts strong decadal minima in the first half of the 19th century and decadal maxima in the $1920 \mathrm{~s}$ and 2000s. It however shows weaker multidecadal trends, both in the second part of the 19th century and during the last decades. From 1979 to 2007, accumulation has increased by $1.6 \mathrm{~cm} \mathrm{yr}^{-1}$, per decade. However, the accumulation rate in the beginning of the 21st century (2000-2011) lies within the average values encountered in the 1920s and 1870s. Similarly, while the $\delta^{18} \mathrm{O}$ record displays a much more pronounced minimum in 1836-1846 compared to 1815-1825, the accumulation record shows similar magnitudes for these two minima (Fig. 3). Note also that record years do not always coincide in $\delta^{18} \mathrm{O}$ and accumulation. For instance, peak accumulation is encountered in 1933, followed by 1928 . A remarkable dry and cold year appears to be 1983, while the years 1878, 1933, 2001, 1892 and 1928 appear partic- 


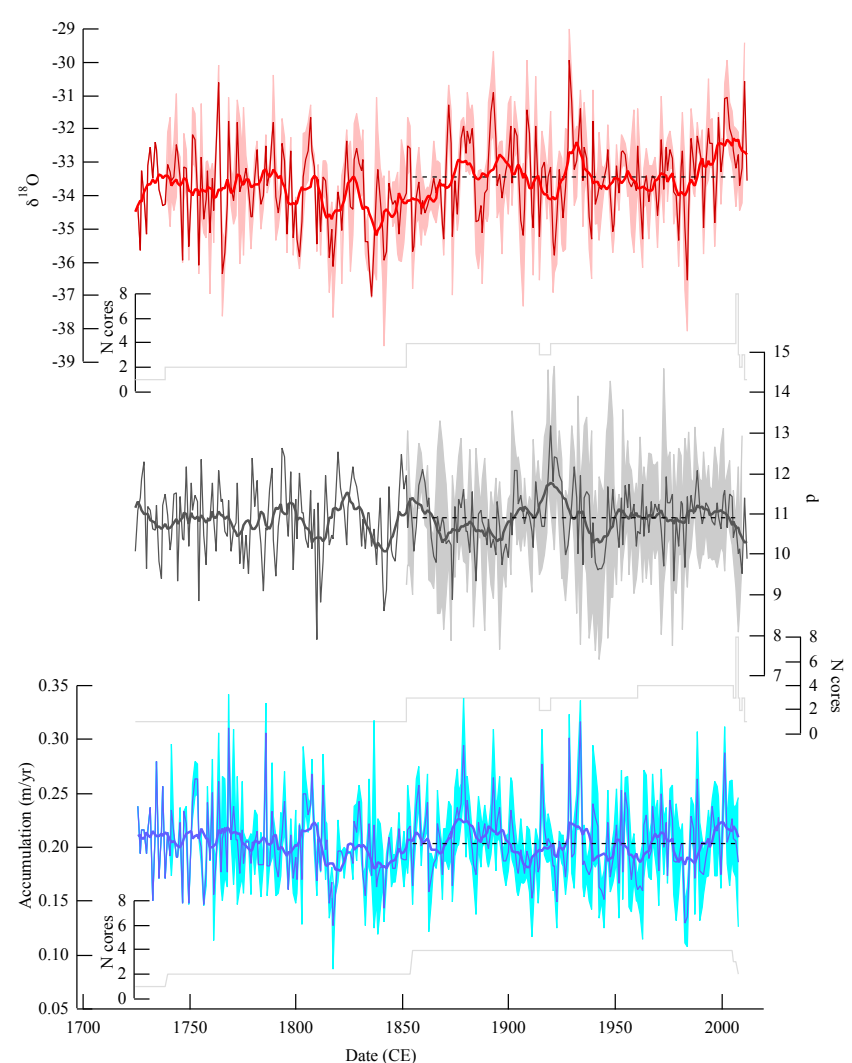

Figure 2. NEEM records from shallow ice cores and snow pits; from top to bottom: $\delta^{18} \mathrm{O}$, deuterium excess ("d") (both reported in $\% o$ ) and accumulation (in $\mathrm{m} \mathrm{yr}^{-1}$ ). The thin coloured lines represent annual averages, and the shading the standard deviation within individual ice core records. The thick lines display 11-year binomial smoothing. The horizontal dotted line shows the average values from 1850 to 2011 . The dashed black lines display the number of shallow ice core records through time (from 1 to 4) as well as the number of pit records (from 1 to 10) spanning 2003-2011. No accumulation estimate is available from these pit data due to the lack of systematic density measurements.

ularly warm and wet. We will further investigate the spatial structure of remarkable wet years, and cold and dry decades in Sects. 4.5.2 and 4.5.3.

For the period 1958-2007, this close relationship between accumulation and $\delta^{18} \mathrm{O}$ has a slope of $1.8 \pm 0.3 \mathrm{~cm} \mathrm{yr}^{-1} \% o^{-1}$ ( $R=0.63$ ). It is smaller than the one obtained from multi-site decadal averages in NW Greenland (Camp Century, NEEM, NGRIP and B26) (2.1 cm w.e. $\mathrm{yr}^{-1} \% o^{-1}$ ) (Buchardt et al., 2012).

The power spectra of accumulation and $\delta^{18} \mathrm{O}$ have different properties. Accumulation has white-noise characteristics and exhibits significant periodicities at 19 years (99\% confidence level, tested using MTM and SSA methods), 7.8 years and 4.3 years ( 90 to $95 \%$ confidence level). In contrast, the power spectrum of $\delta^{18} \mathrm{O}$ is characteristic of a red-noise process. Significant periodicities are detected again at 19 years
(90\% confidence level), and also at 5 years $(95 \%)$ and $\sim 4$ years (99\% confidence). The coherence between these two records is maximum and significant at the $99 \%$ confidence level at the inter-annual scale (3-5 years) and at the bi-decadal scale (Fig. 3). The relationship between accumulation and $\delta^{18} \mathrm{O}$ will be further discussed and compared with model results in Sect. 4.1.

The deuterium excess stack appears quite flat, with no remarkable long-term trend, consistent with the GRIP deuterium excess low-resolution record obtained from two cores (Hoffmann et al., 2001). For the common period (17251979), our NEEM record shows 2.3 times more variance (from 2-year-average data) than this GRIP stack. There was no correlation between the original GRIP source records (when considering mean values over 2 to 20 years). Note that the quality of the NEEM stacked record is lower prior to 1958 due to the use of only three shallow ice cores. For 19582007, the stack NEEM deuterium excess has a mean value of $10.9 \pm 0.6 \%$ o. In Greenland surface snow, deuterium excess generally increases with $\delta^{18} \mathrm{O}$ depletion (Masson-Delmotte et al., 2005). NEEM deviates from this overall spatial pattern by its high deuterium excess level for the corresponding mean $\delta^{18} \mathrm{O}$ level. It also displays multidecadal variability with maximum values in the $1790 \mathrm{~s}, 1820 \mathrm{~s}, 1850 \mathrm{~s}$ and $1920 \mathrm{~s}$, and it shows low values during the period 2005-2010, although such values are not unusual in the context of earlier decadal minima (e.g. 1940s). From 1979 to 2007, no trend is detected in deuterium excess. No significant statistical relationship emerges between NEEM deuterium excess and $\delta^{18} \mathrm{O}$ or accumulation records. The lack of strong signals in recent deuterium excess is surprising, as one could have expected a relationship with recent changes in Arctic sea ice cover $(\mathrm{Ku}-$ rita, 2011; Steen-Larsen et al., 2013). It could arise from the low signal-to-noise ratio. If the lack of long-term trend is a robust feature, this would rule out major changes in moisture origin during the past centuries. We note that - in the combination of $\delta^{18} \mathrm{O}$, accumulation and deuterium excess - there is no earlier analogue to the values observed during the last decade (record high $\delta^{18} \mathrm{O}$ together with high accumulation and low deuterium excess).

\subsection{Comparison with other Greenland ice core records}

We have calculated the inter-annual correlation coefficients of NEEM $\delta^{18} \mathrm{O}$ and accumulation with other Greenland records, as well as with their respective PC1, for the period 1761-1966. We have also tested correlation calculations with de-trended records. Tables S1 and S2 in the Supplement report the detailed results.

For $\delta^{18} \mathrm{O}$ (Table $\mathrm{S} 1$ in the Supplement, Fig. 4), NEEM data are, as expected, weakly correlated with data from south or east Greenland ( $R=0.15$ to 0.25 ) and more strongly correlated with data from central Greenland ( $R=0.30$ with GISP2) and specifically with the closest north-west Greenland records $(R>0.40$ with B29 and NGRIP). Note that the 


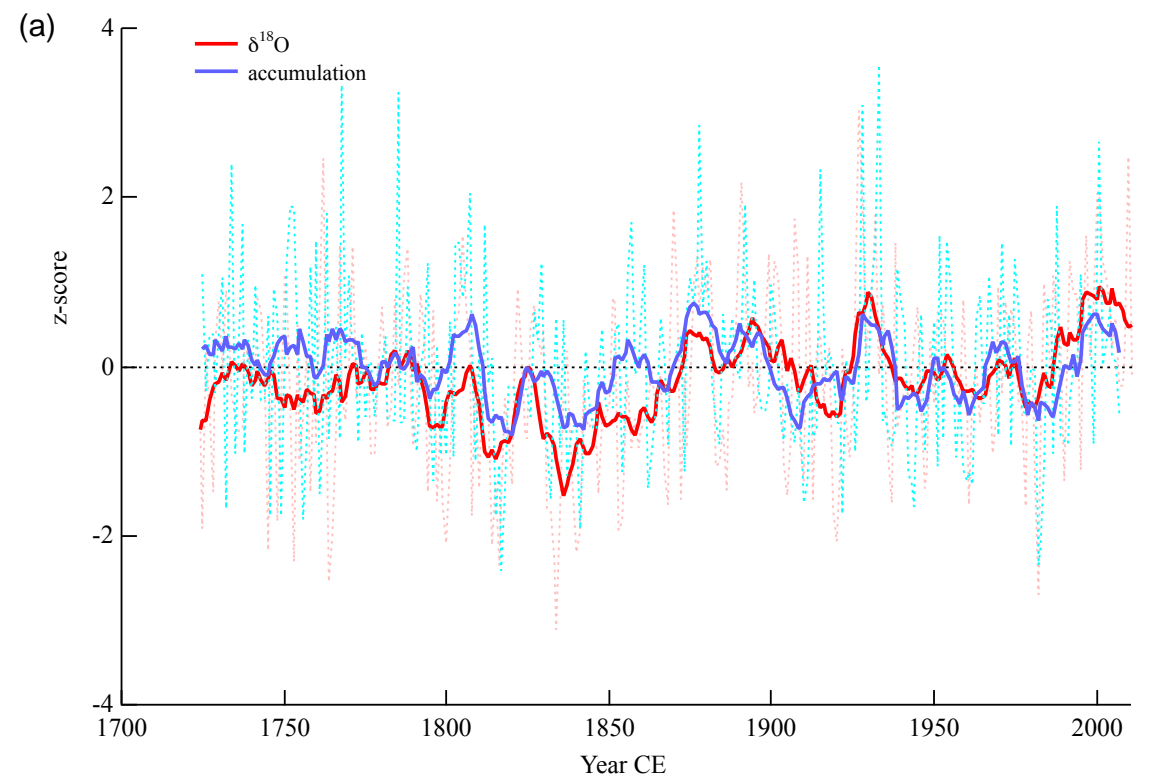

(b)
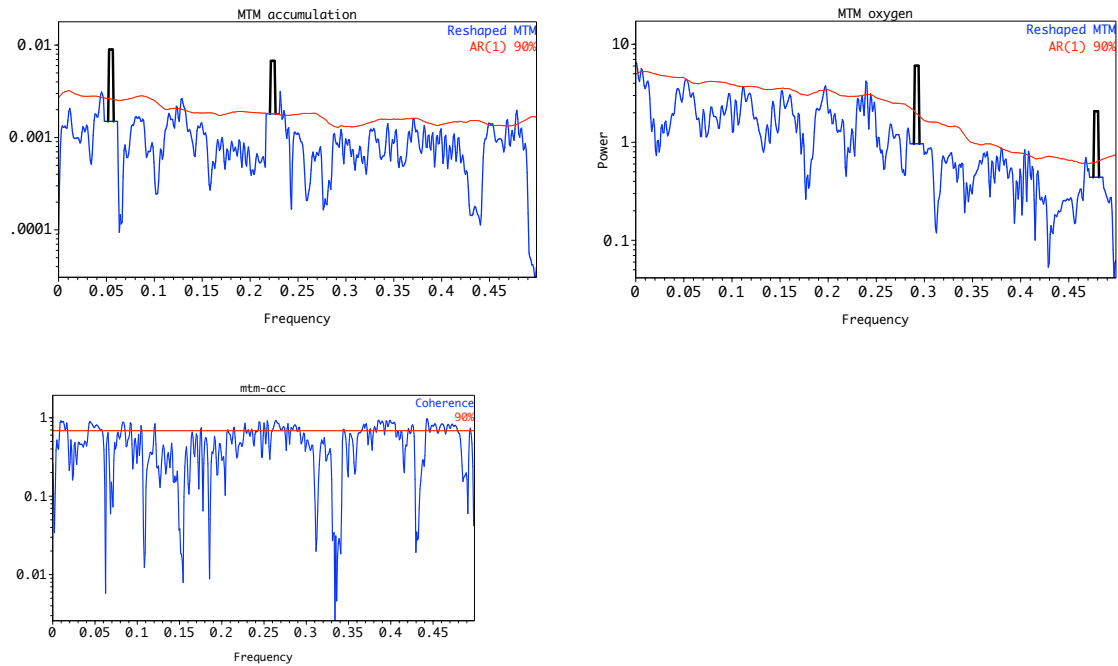

Figure 3. (a) Comparison of $z$ scores of accumulation (blue) and $\delta^{18} \mathrm{O}$ (red) (dashed lines: annual values; thick solid lines: 11-year-average values). Power spectrum of accumulation (b), $\delta^{18} \mathrm{O}(\mathbf{c})$ and coherency (d) calculated using the multitaper method (resolution of 2 , three tapers, adaptative spectrum in blue, tested against compatible white- or red-noise processes shown here in red at $90 \%$ confidence level). Harmonic signals (spikes in the spectrum corresponding to a periodic or quasi-periodic signal in frequency, amplitude and phase) are shown with a black rectangle.

strength of this correlation also depends on the signal-tonoise ratio of each ice core record and is therefore enhanced when comparing NEEM results with stacks obtained from multiple shallow ice cores (e.g. GRIP).

The correlation coefficient between NEEM $\delta^{18} \mathrm{O}$ and the PC1 of all Greenland annual $\delta^{18} \mathrm{O}$ records spanning 1761 to 1966 (Ortega et al., 2014) is 0.48 at annual scale and increases to 0.67 for 5 -year-average data. NEEM $\delta^{18} \mathrm{O}$ and Greenland $\delta^{18} \mathrm{O}$ PC1 (Fig. 5) share common inter-annual $\left(R^{2}=0.24\right)$ and multidecadal $\left(R^{2}=0.51\right)$ variations.
Altogether, the spatial patterns of correlations with NEEM accumulation are similar but with smaller strength than those of $\delta^{18} \mathrm{O}$ (Fig. 4). The NEEM accumulation record (Table S2 in the Supplement, Fig. 4) is only weakly correlated (at annual scale) with records from south Greenland (e.g. $R=0.11$ with DYE2, $p=0.05$ ) and central Greenland (e.g. $R=0.15$ with GRIP, $p=0.01)$. We again observe the strongest relationship with the closest ice cores (B29, Camp Century and NGRIP) where correlation coefficients reach $R=0.38$ $(p=0.000)$, albeit with one exception (B26, insignificant 

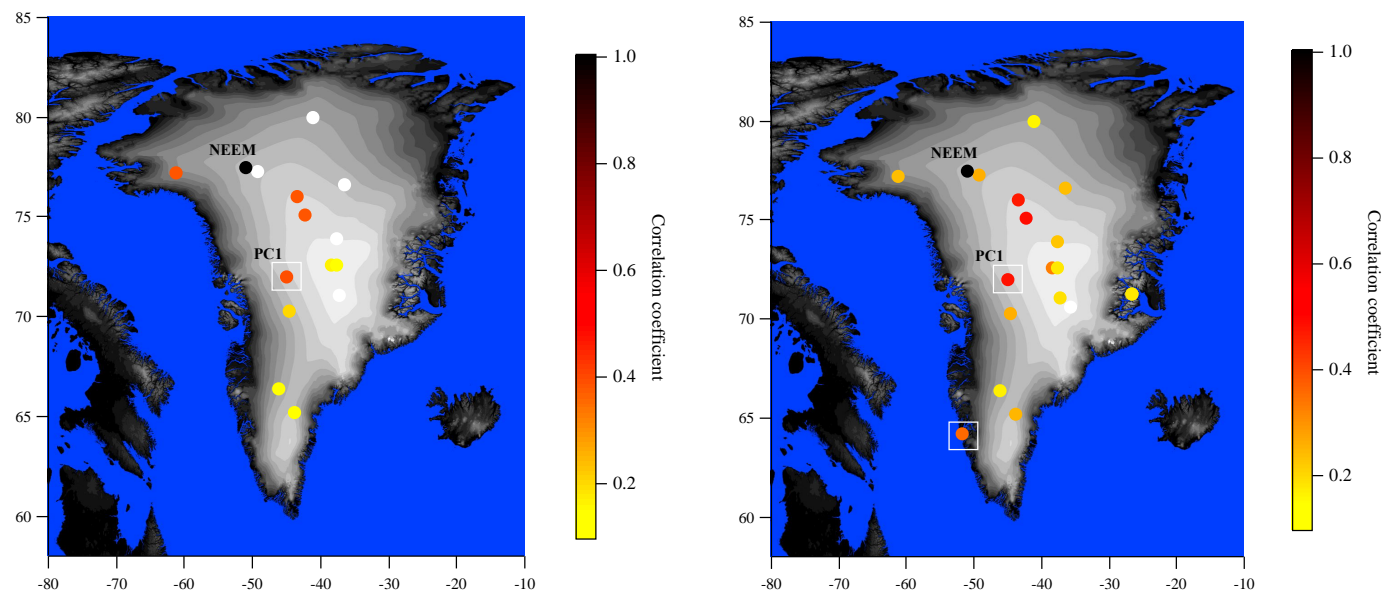

Figure 4. Spatial distribution of correlation coefficients between NEEM accumulation (top) and other Greenland accumulation records, and between NEEM $\delta^{18} \mathrm{O}$ (bottom) and other Greenland temperature and $\delta^{18} \mathrm{O}$ records. We have also displayed the correlation with the PC1 of other Greenland records (white rectangle) and the correlation with SW Greenland instrumental temperature data (repeating the same value for the three coastal sites used to make the temperature stack record) (white rectangles). We used correlation coefficients for the same period (1761-1966), without detrending (Tables S1, S2 and S3 in the Supplement). Note that insignificant correlations are represented by the white filled circles.

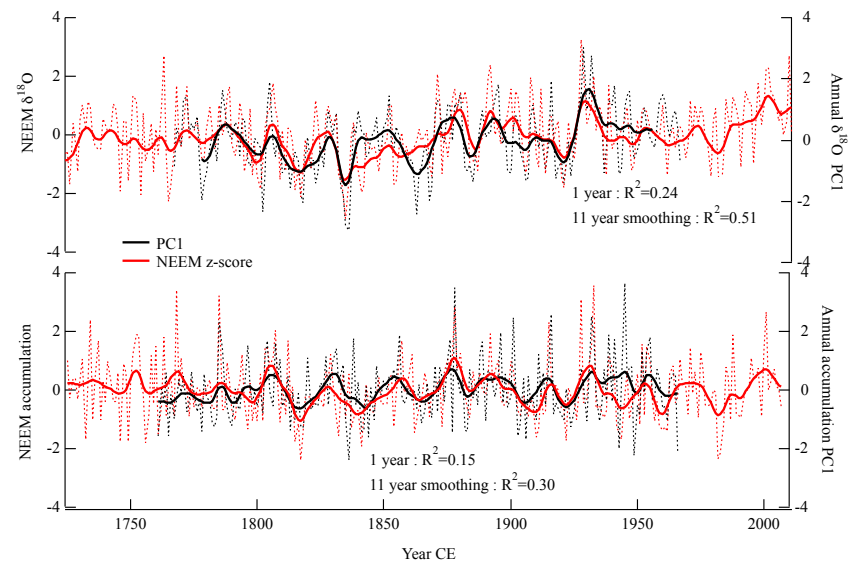

Figure 5. Top: comparison between NEEM $\delta^{18} \mathrm{O} z$ score (red, no unit) with the first principal component (PC1) of 16 Greenland annual $\delta^{18} \mathrm{O}$ records (Ortega et al., 2014) (black, no unit). Bottom: comparison between NEEM $\delta^{18} \mathrm{O} z$ score (red, no unit) with the first principal component (PC1) of 13 Greenland annual accumulation records (common with those used for $\delta^{18} \mathrm{O}$ ) calculated using the same methodology as published for $\delta^{18} \mathrm{O}$ (black, no unit; see Fig. S1 in the Supplement). Annual mean data are shown as dotted lines, and 11-year binomial averages are shown as bold lines. We also report the respective coefficients of determination between the annual mean NEEM data and the PC1 ( $p$ values are lower than $\left.10^{-9}\right)$.

correlation). By contrast, the correlation with Camp Century is stronger for accumulation than for $\delta^{18} \mathrm{O}$. These correlations increase for low frequencies $(R=0.63$ with NGRIP for 5 -year-average data).
The correlation between NEEM accumulation and the Greenland accumulation stack (Andersen et al., 2006), which mostly relies on ice cores from south and central Greenland, is only 0.28 at annual scale and 0.27 for 5 -year-average data (not shown). Both the NEEM accumulation record and the Greenland accumulation stack depict an increase in multidecadal variability in the 19th century, but they diverge in the 1970s (not shown). This would deserve to be further explored, for instance by investigating patterns of moisture transport towards NEEM during this time period, which is marked by a retreat of Baffin Bay sea ice cover and out-of-phase changes between the Labrador and Norwegian seas (Drinkwater et al., 2013). The correlation between the NEEM accumulation record and the PC1 of accumulation is much higher than with the south-central Greenland accumulation stack (Table S2 in the Supplement). This coherency is maximum at the decadal scale, reaching $R^{2}=0.30$ (Fig. 5). At this decadal scale, we note that both NEEM accumulation and accumulation PC1 depict a sharper minimum in the 1810 s compared to the 1830 s, in contrast with the $\delta^{18} \mathrm{O}$ data. We also observe that the coherency between NEEM and accumulation PC1 is less good in the most recent overlapping period (1940s to 1960s), without identifying a clear explanation for this feature.

This comparison stresses the quality of the Greenlandscale climate information archived in the NEEM stack $\delta^{18} \mathrm{O}$ and accumulation records, and it identifies specific features of NEEM regional variability. These specificities will be further explored in Section 4.4 by mapping the spatial structure associated with remarkable cold-dry and warm-wet years and decades. 


\subsection{Comparison with regional climate}

In this section and the following parts of this manuscript, we systematically report correlation coefficients $(R)$ and not determination coefficients $\left(R^{2}\right)$ as results of statistical analyses, to inform as well about the sign of the relationship.

The NEEM $\delta^{18} \mathrm{O}$ and accumulation records are significantly correlated with the historical record of south-west Greenland instrumental temperature (Table S3 in the Supplement). For accumulation, correlation coefficients are comparable for winter (DJFM) and summer (JJAS), around $R=0.25$. For $\delta^{18} \mathrm{O}$, stronger correlation coefficients are identified, from 0.32 (DJFM) to 0.49 (JJAS) (Table S3 in the Supplement), with 0.44 for annual mean temperature (not shown). We note that the strength of the correlation of NEEM $\delta^{18} \mathrm{O}$ with coastal SW Greenland temperature is comparable to the strength of its correlation with the $\delta^{18} \mathrm{O} \mathrm{PC} 1$.

The NEEM $\delta^{18} \mathrm{O}$, deuterium excess and accumulation are also significantly correlated with North Atlantic SST (Fig. 6). The correlation patterns are similar when using annual, 5and 10-year smoothed data, and the strength of the correlation is larger for 5- and 10-year smoothed data. NEEM $\delta^{18} \mathrm{O}$ and accumulation are positively related to SST in the subpolar gyre, with a stronger relationship for $\delta^{18} \mathrm{O}$ than for accumulation. Deuterium excess is negatively related to SST, with a weak correlation coefficient which may arise from the low signal-to-noise level in our data set (Fig. 6). This can be understood through the fact that a warmer North Atlantic favours enhanced evaporation and subsequently becomes a dominant moisture source to NEEM. A larger contribution of nearby moisture sources is expected to favour warmer and wetter conditions, reduced en-route distillation and less depleted $\delta^{18} \mathrm{O}$ than for long-distance moisture transport, or for Arctic moisture. Similarly, a larger contribution of North Atlantic moisture formed under relatively wet evaporation conditions is expected to produce a smaller deuterium excess than for Arctic air masses, associated with stronger kinetic evaporation at sea ice margins, and therefore higher deuterium excess. We assume that surface humidity effects would be dominant over surface temperature effects. These patterns are fully consistent with the information provided by surface water vapour monitoring recently achieved in south Greenland (Bonne et al., 2014) and at NEEM (Steen-Larsen et al., 2013), which support this interpretation.

These analyses confirm that the NEEM ice cores record large-scale temperature information. In the next section, we will therefore investigate the relationship between NEEM records and modes of variability.

\subsection{Comparison with modes of variability}

NEEM accumulation and $\delta^{18} \mathrm{O}$ records only display a weak but significant anti-correlation with winter and summer NAO (Table S3 in the Supplement), much smaller than for south Greenland ice cores, where the correlation coefficient is be-
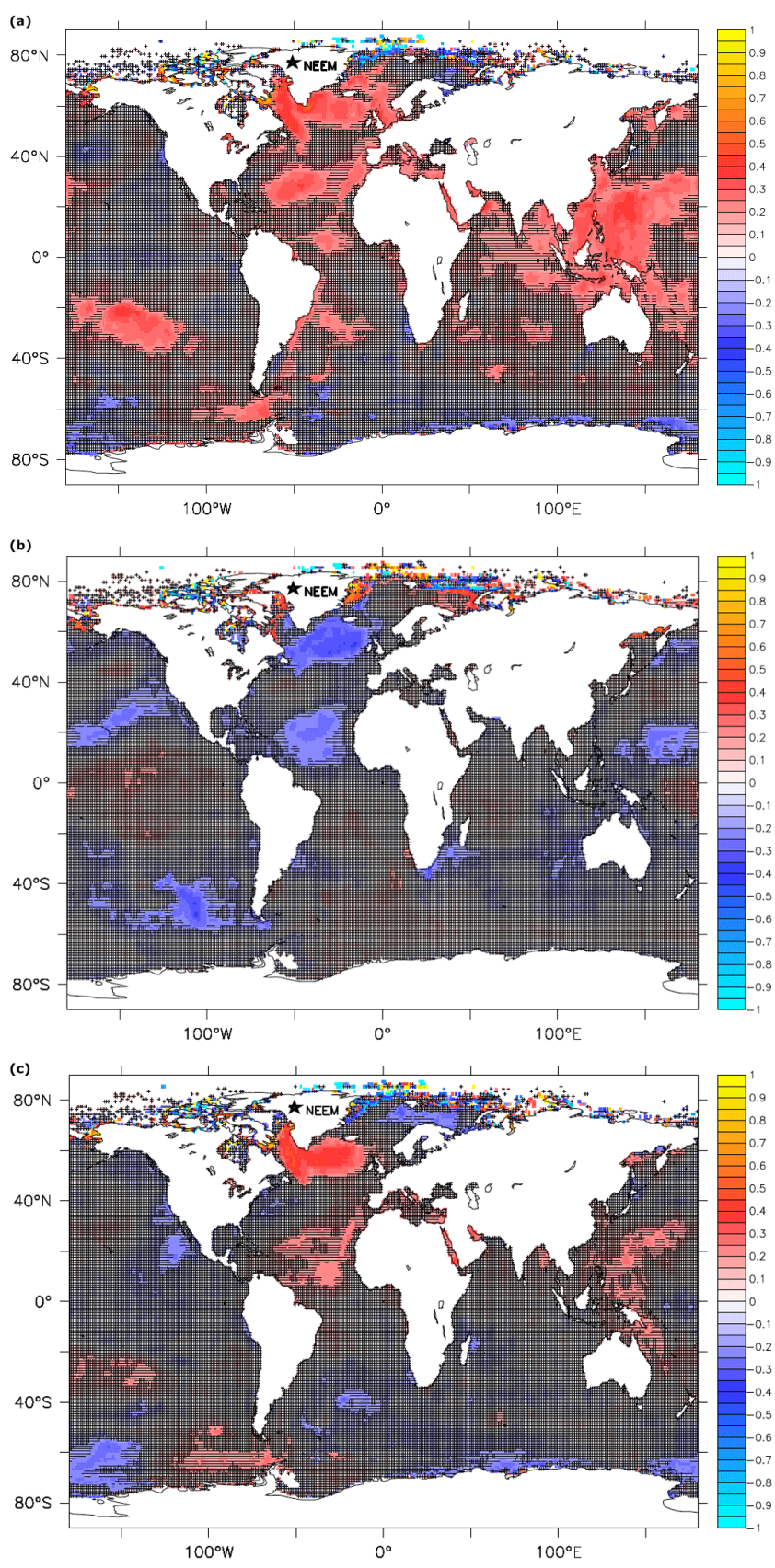

Figure 6. Correlation coefficients between NEEM $\delta^{18} \mathrm{O}$, accumulation and deuterium excess records and HadSST gridded SST data, using 5-year smoothed data, for the period 1870-2010. The hatching highlights areas where correlation coefficients are not significant at the $95 \%$ confidence level. From top to bottom: (a) $\delta^{18} \mathrm{O}$, (b) accumulation and (c) deuterium excess.

low -0.3 (Vinther et al., 2003; Ortega et al., 2014). The statistical relationship between the NEEM and south Greenland ice cores may therefore arise from this simultaneous impact of the NAO imprint in each region.

The last decade is marked by changes in circulation patterns, with the emergence of the Arctic dipole (Zhang et al., 
2008). In order to investigate the fingerprints of large-scale Arctic atmospheric circulation in Greenland ice cores, we have performed a linear correlation analysis of the two first principal components of sea level pressure north of $70^{\circ} \mathrm{N}$ and NEEM records (Table S4 in the Supplement). The first component is related to the Arctic Oscillation (AO), while the second component is related to the Arctic dipole (not shown). Due to uncertainties in the early part of the pressure data set (prior to 1930), we have tested the robustness of correlations for two time periods (1870-2010 and 1930-2010) and for different data smoothing (no smoothing, 3 and 5 years). Correlations are strongest and most stable $(R>0.3)$ for NEEM $\delta^{18} \mathrm{O}$ and accumulation with $\mathrm{AO}$ and the Arctic dipole at 3-5 year smoothing, while, despite its low signal-to-noise ratio, deuterium excess is only significantly correlated with $\mathrm{AO}$ at 5 year smoothing.

We have also investigated the statistical linear relationships between NEEM records and the four main North Atlantic weather regimes for winter (DJFM) and summer (JJAS) (Table S5 in the Supplement). For winter weather regimes, the only statistically significant correlation emerges for $\delta^{18} \mathrm{O}$ with the Atlantic Ridge regime, thus confirming its influence over northern Greenland (Ortega et al., 2014). For summer weather regimes, despite its low signal-to-noise ratio, deuterium excess is significantly anti-correlated with Scandinavian blocking, while no robust feature emerges for NEEM accumulation, and NEEM $\delta^{18} \mathrm{O}$ is significantly correlated with $\mathrm{NAO}-$ and anti-correlated with $\mathrm{NAO}+$ (Table S5 in the Supplement). We have also tested the correlation of NEEM records with Greenland blocking (Hanna et al., 2013), which is known to have a strong imprint on coastal Greenland summer temperature and melting. We also detect a significant positive correlation between the Greenland blocking index (same as in Hanna et al., 2013) and both NEEM annual mean $\delta^{18} \mathrm{O}(1948-2011, R=0.29)$ and NEEM accumulation (1948-2007, $R=0.26$ ) (not shown).

We conclude that the inter-annual climate variability at NEEM is only weakly driven by North Atlantic or Arctic weather regimes and atmospheric modes of variability. This variability seems more likely dominated by changes in the sub-polar North Atlantic.

As expected from the spatial patterns of correlation between NEEM data and North Atlantic SST (Fig. 6), significant correlation is detected between NEEM records and different indices of the Atlantic Multidecadal Oscillation. The strength of this correlation increases using low-pass filtered data, and it peaks with a 2-year lag. For 11-year running averages (not shown), it reaches up to 0.44 for $\delta^{18} \mathrm{O}$, and it is slightly lower for accumulation. A recent proxy-based AMO reconstruction (AMO3) only shows significant correlation with deuterium excess. This is consistent with observations showing large changes in deuterium excess, with lower values for North Atlantic moisture and higher values for Arctic moisture (Kurita, 2011; Bonne et al., 2014; Steen-Larsen et al., 2013).
At multi-annual and longer timescales, the NEEM ice core records may therefore be closely related to changes in North Atlantic Ocean circulation. This provides an explanation for the close relationship between NEEM records and the PC1 of other Greenland ice cores, in which contrasted regional impacts of weather regimes are damped.

\section{Discussion: comparison of NEEM data with reconstructions and simulations}

\subsection{Accumulation}

We first compare the NEEM accumulation record with outputs of the Greenland gridded accumulation reconstruction as well as with annual mean precipitation from nudged simulations performed with MAR, ECHAM5-wiso and LMDZiso - at the grid points closest to NEEM (Fig. 7). We note that the use of precipitation instead of the net surface mass balance introduces artefacts in this comparison, as we do not account for sublimation, deposition or wind erosion. Sublimation is negligible in all simulations. Only MAR accounts for deposition and wind erosion effects. In this model, deposition represents an additional mass gain of $12 \%$ at NEEM (not shown).

While average precipitation in the different sets of MAR simulation is in very good agreement with NEEM data, we observe a dry bias in the gridded reconstruction and in both LMDZiso simulations, as well as a wet bias for ECHAM5wiso-ERA. The magnitude of the inter-annual standard deviation appears proportional to the mean accumulation value, and therefore the inter-annual variability is underestimated for models with a dry bias and overestimated for those with a wet bias. The inter-annual variability of MAR-simulated precipitation is larger (13 to $29 \%$ ) than the observed variability of NEEM accumulation.

The correlation coefficient between the NEEM record and these data sets (Table 2) varies from 0.5 (LMDZiso-20CR and reconstruction) to 0.8 (MAR and ECHAM5-wiso using ERA atmospheric fields). Prior to 1958, the historical LMDziso-20CR simulation and the reconstruction perform quite poorly. Within the time interval common to all simulations, better agreement is observed when using ERA then when using NCEP or 20CR reanalyses (based on LMDZiso and MAR simulations).

We observe an increasing trend from 1979 to 2007 by $1.6 \mathrm{~cm}$ w.e. $\mathrm{yr}^{-1}$, per decade (Table 2). This increasing trend is well captured by all MAR simulations and LMDZERA, underestimated by LMDZiso-20CR (which has a dry bias), and slightly overestimated (but within uncertainties) by ECHAM5-wiso-ERA (which has a wet bias).

\section{2 $\quad \delta^{18} \mathrm{O}$ and deuterium excess}

We now compare the NEEM $\delta^{18} \mathrm{O}$ record with precipitationweighted $\delta^{18} \mathrm{O}$ from nudged simulations performed with the 
Table 2. Comparison of NEEM accumulation (cm water equivalent per year) with gridded data from the reconstruction (Box et al., 2012) and from simulations. The mean values and standard deviations are reported for 1958-2007.

\begin{tabular}{llllll}
\hline $\begin{array}{l}\text { Accumulation } \\
\left(\mathrm{cm} \text { w.e. } \mathrm{yr}^{-1}\right)\end{array}$ & $\begin{array}{l}\text { Mean } \\
1958-2007\end{array}$ & $\begin{array}{l}\text { Standard deviation } \\
1958-2007\end{array}$ & $R$ & $R$ before 1958 & $\begin{array}{l}\text { Trend per decade } \\
1958-2007\end{array}$ \\
\hline NEEM & 20.2 & 3.1 & & & $1.6 \pm 0.7$ \\
MARv3.4-ERA (1958-2007) & 19.5 & 4.0 & $0.79(p=0.000)$ & & $1.8 \pm 0.8$ \\
MARv3.4-NCEP (1948-2007) & 20.6 & 3.6 & $0.68(p=0.000)$ & $0.61(p=0.027)$ & $1.4 \pm 0.8$ \\
MARv3.4-20CR (1871-2007) & 19.8 & 4.2 & $0.71(p=0.000)$ & $0.57(p=0.000)$ & $1.7 \pm 0.9$ \\
ECHAM5-wiso-ERA (1958-2007) & 29.1 & 5.4 & $0.76(p=0.000)$ & & $2.0 \pm 1.2$ \\
LMDZiso-20CR (1871-2007) & 14.0 & 2.3 & $0.53(p=0.000)$ & $0.23(p=0.003)$ & $0.7 \pm 0.5$ \\
LMDZiso-20CR (1979-2007) & 14.0 & 2.4 & $0.69(p=0.000)$ & & $0.7 \pm 0.5$ \\
LMDZiso-ERA (1979-2007) & 16.0 & 2.3 & $0.59(p=0.000)$ & & $1.3 \pm 0.5$ \\
Reconstruction (1840-1999) & 21.4 & 2.3 & $0.53(p=0.000)$ & $0.19(p=0.018)$ & not available \\
& & & & & up to 2007 \\
\hline
\end{tabular}

Table 3. Comparison of NEEM $\delta^{18} \mathrm{O}$ with simulations.

\begin{tabular}{lllcl}
\hline$\delta^{18} \mathrm{O} \% o$ & Mean & $\begin{array}{l}\text { Standard } \\
\text { deviation }\end{array}$ & $R$ & $\begin{array}{l}\text { Trend per decade } \\
1979-2007\end{array}$ \\
\hline NEEM (1958-2007) & -33.4 & 1.1 & & $0.77 \pm 0.25$ \\
ECHAM5-wiso-ERA (1958-2007) & -29.0 & 1.0 & $0.68(p=0.000)$ & $0.69 \pm 0.18$ \\
LMDZiso-20CR (1958-2007) & -26.8 & 0.6 & $0.41(p=0.002)$ & $0.19 \pm 0.12$ \\
LMDZiso-20CR (1979-2007) & -26.6 & 0.5 & $0.40(p=0.015)$ & $0.19 \pm 0.12$ \\
LMDZiso-ERA (1979-2007) & -26.3 & 1.0 & $0.75(p=0.000)$ & $0.82 \pm 0.17$ \\
\hline
\end{tabular}

models resolving water-stable isotopes (ECHAM5-wiso and LMDZiso), at the grid points closest to NEEM (Fig. 8, Table 3). Models underestimate the $\delta^{18} \mathrm{O}$ depletion at NEEM by 4.4\%o (ECHAM5-wiso-ERA) to 6.8\%o (LMDZiso-20CR). The correlation coefficient between the simulated and observed $\delta^{18} \mathrm{O}$ is 0.68 (1958-2007) for ECHAM5-wiso-ERA, and 0.75 (1979-2007) with LMDZiso-ERA. The LMDZiso20CR simulation underestimates isotopic variability by a factor of 2 , shows a comparatively lower correlation $(R=0.41$, 1958-2007) and does not reproduce the recent increasing trend. The correlation strength between LMDZiso-20CR and NEEM $\delta^{18} \mathrm{O}$ is stable at $R=0.40$ from 1930 onward; prior to 1930 , it drops to about $R=0.20$ (with or without detrending). All the other simulations perform reasonably well in terms of their ability to capture the observed trend from 1979 to 2007 ( $0.77 \pm 0.25 \%$ o per decade). Again, simulations nudged to ERA perform better than those nudged to 20CR.

One reason for the specific features of the LMDZiso20CR simulation lies in the atmospheric reanalyses themselves. The 20CR reanalyses provide an ensemble of realisations which are consistent with the assimilated data. The nudging of LMDZiso was performed using the average winds of all $20 \mathrm{CR}$ ensemble members, leading to a strong smoothing of synoptic variability. An alternative choice could be to drive the atmospheric model using a randomly selected member of the 20CR ensemble.

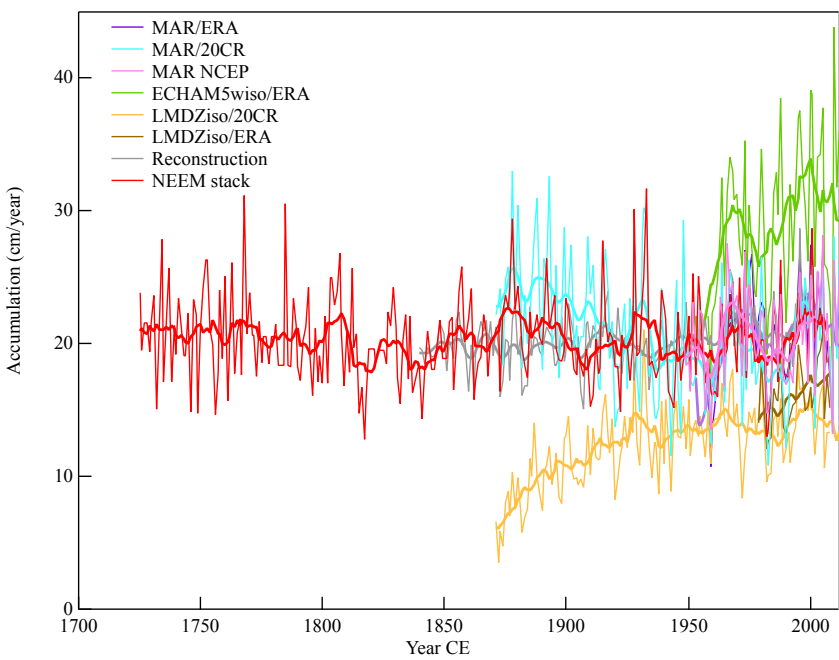

Figure 7. Comparison of NEEM accumulation with the reconstruction and precipitation from simulations, in $\mathrm{cm}$ of water equivalent per year. Results are shown for annual averages, as well as for a 11-year binomial smoothing.

We can also compare the accumulation $-\delta^{18} \mathrm{O}$ relationships from NEEM with those from the simulations (Fig. 9). In addition to its wet and $\delta^{18} \mathrm{O}$-enriched bias, ECHAM5-wiso-ERA produces a stronger accumulation$\delta^{18} \mathrm{O}$ slope than observed $\left(2.6 \pm 0.8 \mathrm{~cm} \mathrm{yr}^{-1} \% o^{-1}\right.$ compared 
Table 4. Comparison of NEEM deuterium excess with simulations, performed for 1958-2007 and for 1979-2007.

\begin{tabular}{llrcr}
\hline Time span & Deuterium excess (\%o) & Mean & $\begin{array}{c}\text { Standard } \\
\text { deviation }\end{array}$ & $R$ with NEEM \\
\hline $1958-2007$ & NEEM & 10.9 & 0.6 & \\
$1958-2007$ & ECHAM5-wiso ERA & 10.8 & 0.6 & $0.47(p=0.000)$ \\
$1958-2007$ & LMDZiso 20CR & 11.7 & 0.4 & $0.27(p=0.029)$ \\
$1979-2007$ & LMDZiso 20CR & 11.5 & 0.3 & $0.34(p=0.035)$ \\
$1979-2007$ & LMDZiso ERA & 3.8 & 0.6 & $-0.32(p=0.045)$ \\
\hline
\end{tabular}

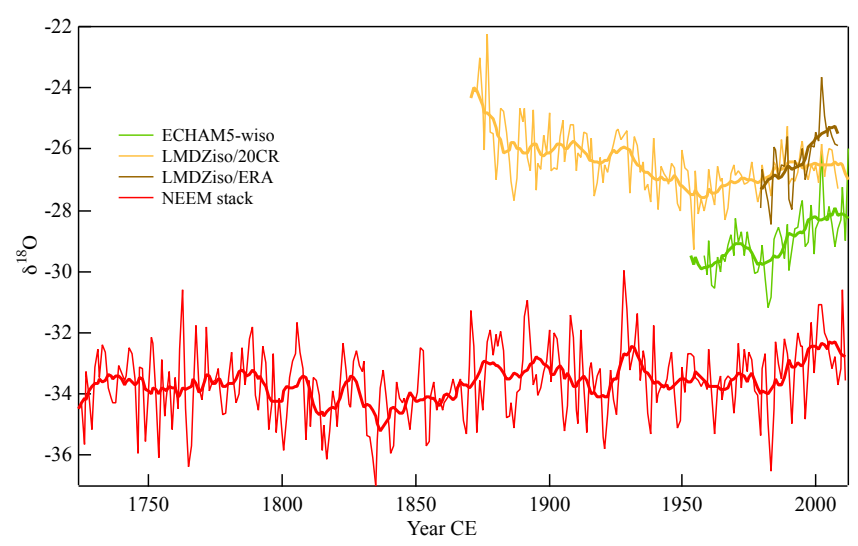

Figure 8. Comparison of NEEM $\delta^{18} \mathrm{O}$ with $\delta^{18} \mathrm{O}$ simulations (in $\%$ ).

to $1.8 \pm 0.3 \mathrm{~cm} \mathrm{yr}^{-1} \% o^{-1}$ from NEEM data, 1958-2007) but shows more dispersion $(R=0.44)$ than observed $(R=0.63)$ (not shown). In ECHAM5-wiso, model biases are at least partly related to the coarse resolution of the T63 simulation. This is demonstrated for the period 1980-2012 through the comparison of a T63 and a T106 simulation (both nudged to ERA-Interim). At NEEM, the T106 simulation (not shown) produces lower temperatures $\left(\Delta=-2.9{ }^{\circ} \mathrm{C}\right.$ ) and more depleted $\left(\Delta \delta^{18} \mathrm{O}=-1.7 \%\right.$ ) and slightly reduced precipitation amounts $\left(\Delta=-0.8 \mathrm{~cm} \mathrm{yr}^{-1}\right)$ compared to the T63 simulation. LMDZiso-ERA strongly underestimates the strength of the observed relationship, with a slope of $1.1 \pm 0.4 \mathrm{~cm} \mathrm{yr}^{-1} \% o^{-1}(1979-2007, R=0.44)$, as compared with the observed slope $\left(2.0 \pm 0.4 \mathrm{~cm} \mathrm{yr}^{-1} \%^{-1}\right.$, 19792007, $R=0.69$ for NEEM); in the LMDZiso-20CR simulation, no relationship is observed between these two variables. This again suggests a better representation of synoptic weather systems in ERA than 20CR, and caveats in moisture advection towards north-west Greenland in LMDZiso and ECHAM5-wiso at T63 resolution, possibly related to the low spatial resolution of the models, which may not resolve correctly the small-scale storms observed in this area.

We finally note that the observed and simulated recent accumulation- $\delta{ }^{18} \mathrm{O}$ temporal relationship differs from the relationship inferred from the the Holocene NEEM chronology (2.5 cm water equivalent according to S. L. Buchardt, 2014).

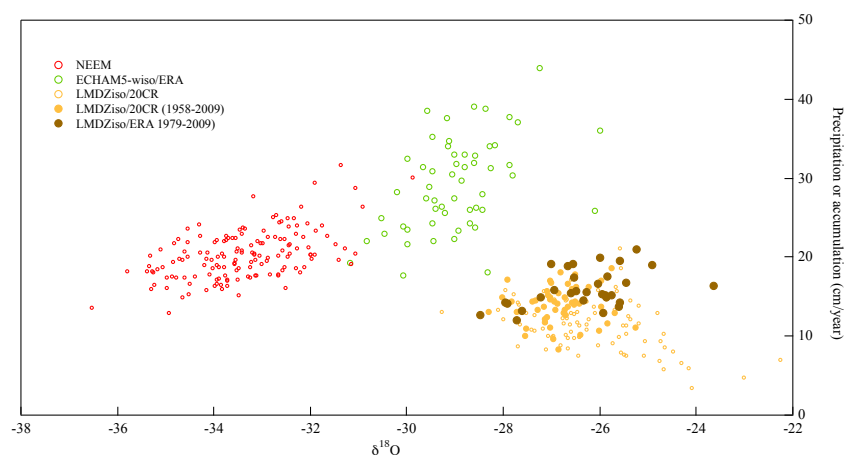

Figure 9. Relationship between accumulation or precipitation $(\mathrm{cm}$ water equivalent per year) and $\delta^{18} \mathrm{O}(\% \circ)$ in NEEM ice core stack (red) and in different simulations (colours).

The comparison between simulations and NEEM deuterium excess data (Fig. 10, Table 4) raises further questions. We have already stressed the weak signal-to-noise ratio within the individual NEEM shallow ice core records. With this caveat in mind, we note that ECHAM5-wiso-ERA correctly captures the mean level and variance of deuterium excess at NEEM for 1958-2007, despite its wet and $\delta^{18} \mathrm{O}$ enriched biases. LMDZiso again underestimates the variance using the 20CR simulation and produces very low deuterium excess levels in the ERA simulation. The correlation coefficient is low for all LMDZiso outputs. We observe a significant correlation between ECHAM5-wiso-ERA deuterium excess and NEEM data $(R=0.47)$. Despite the low signalto-noise ratio in our record, this suggests that there could be information on large-scale moisture transport in NEEM deuterium excess, as also suggested by its correlation with NAO.

Finally, both ECHAM5-wiso-ERA and LMDZiso-ERA produce a decreasing trend in deuterium excess during 19792007, while no trend is observed in our NEEM records. This may suggest that models simulate changes in north-west Greenland moisture sources associated with recent warming, which are not supported by the (noisy) NEEM data. Modeldata comparisons with in situ surface water vapour monitoring have shown the caveats of these models which fail to correctly simulate the high deuterium excess associated with air mass trajectories from the Arctic (Steen-Larsen et al., 2013). Issues may also arise from post-deposition effects which are 
Table 5. Comparison of NEEM $\delta^{18} \mathrm{O}$ with temperature reconstructions and simulations.

\begin{tabular}{|c|c|c|c|c|c|c|}
\hline $\begin{array}{l}\text { Temperature } \\
\left({ }^{\circ} \mathrm{C}\right)\end{array}$ & $\begin{array}{l}\text { Mean } \\
1958-2007\end{array}$ & $\begin{array}{l}\text { Standard deviation } \\
\text { 1958-2007 }\end{array}$ & $\begin{array}{l}R \text { with NEEM } \\
\delta^{1} 80 \text { (T) } 1958-2007\end{array}$ & $\begin{array}{l}R \text { with NEEM } \\
\delta^{1} 8 \mathrm{O}(\text { weighted } \mathrm{T})\end{array}$ & $\begin{array}{l}R \text { with NEEM } \\
\delta^{1} 80 \text { before } 1958\end{array}$ & $\begin{array}{l}\text { Trend per decade } \\
\text { 1979-2007 }\end{array}$ \\
\hline $\begin{array}{l}\text { MARv3.4-ERA } \\
\text { 1958-2007 }\end{array}$ & -27.5 & 1.0 & $\begin{array}{l}0.31 \\
(p=0.0015)\end{array}$ & $\begin{array}{l}0.25 \\
(p=0.045)\end{array}$ & & $0.58 \pm 0.22$ \\
\hline $\begin{array}{l}\text { MARv3.4-NCEP } \\
\text { 1948-2007 }\end{array}$ & -27.1 & 1.1 & $\begin{array}{l}0.21 \\
(p=0.077)\end{array}$ & $\begin{array}{l}0.26 \\
(p=0.034)\end{array}$ & $\begin{array}{l}0.62 \\
(p=0.024)\end{array}$ & $0.63 \pm 0.24$ \\
\hline $\begin{array}{l}\text { MARv3.4-20CR } \\
1871-2007\end{array}$ & -26.4 & 1.0 & $\begin{array}{l}0.23 \\
(p=0.051)\end{array}$ & $\begin{array}{l}0.21 \\
(p=0.074)\end{array}$ & $\begin{array}{l}0.33 \\
(p=0.000)\end{array}$ & $0.58 \pm 0.21$ \\
\hline $\begin{array}{l}\text { ECHAM5-wiso-ERA } \\
\text { 1958-2007 }\end{array}$ & -23.0 & 1.2 & $\begin{array}{l}0.43 \\
(p=0.001)\end{array}$ & $\begin{array}{l}0.59 \\
(p=0.000)\end{array}$ & & $0.81 \pm 0.24$ \\
\hline $\begin{array}{l}\text { LMDZiso-20CR } \\
\text { 1958-2007 }\end{array}$ & -19.8 & 0.8 & $\begin{array}{l}0.08 \\
(p=0.290)\end{array}$ & $\begin{array}{l}0.44 \\
(p=0.001)\end{array}$ & $\begin{array}{l}0.08 \\
(p=0.231)\end{array}$ & $0.19 \pm 0.18$ \\
\hline $\begin{array}{l}\text { LMDZiso-20CR } \\
\text { 1979-2007 }\end{array}$ & -19.8 & 0.8 & $\begin{array}{l}0.27 \\
(p=0.078)\end{array}$ & $\begin{array}{l}0.41 \\
(p=0.013)\end{array}$ & & $0.19 \pm 0.18$ \\
\hline $\begin{array}{l}\text { LMDZiso-ERA } \\
\text { 1979-2007 }\end{array}$ & -21.2 & 1.1 & $\begin{array}{l}0.49 \\
(p=0.003)\end{array}$ & $\begin{array}{l}0.67 \\
(p=0.000)\end{array}$ & & $0.65 \pm 0.22$ \\
\hline $\begin{array}{l}\text { Reconstruction } \\
1840-2007\end{array}$ & -31.1 & 1.2 & $\begin{array}{l}0.37 \\
(p=0.004)\end{array}$ & & $\begin{array}{l}0.42 \\
(p=0.000)\end{array}$ & $0.98 \pm 0.22$ \\
\hline \multicolumn{7}{|l|}{$\begin{array}{l}\text { SW coastal } \\
\text { Greenland T }\end{array}$} \\
\hline DJFM & -8.6 & 2.8 & $0.01(p=0.473)$ & & $0.35(p=0.000)$ & $0.95 \pm 0.69$ \\
\hline JJAS & 5.7 & 0.9 & $0.42(p=0.001)$ & & $0.46(p=0.000)$ & $0.61 \pm 0.18$ \\
\hline ANN 1784-2007 & -1.6 & 1.4 & $0.22(p=0.062)$ & & $0.45(p=0.000)$ & $0.83 \pm 0.32$ \\
\hline
\end{tabular}

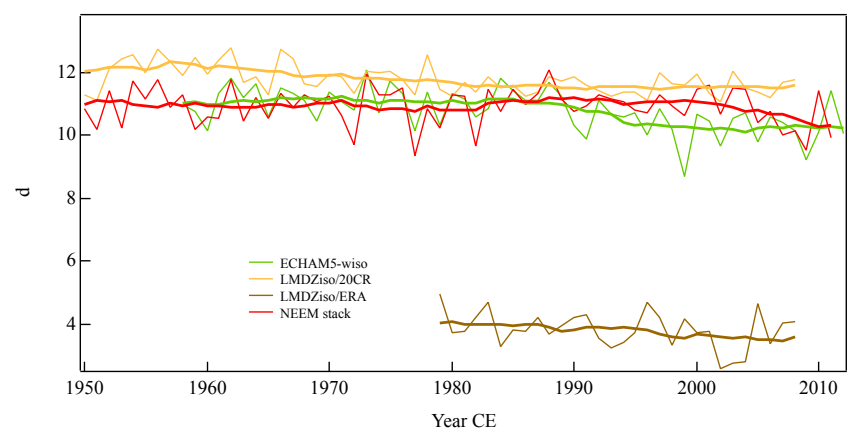

Figure 10. Comparison of NEEM deuterium excess (d, in \%o) with simulations.

not understood (Steen-Larsen et al., 2014). Further investigations are needed, especially with respect to the seasonal trends in deuterium excess in the simulations and ice core records, with the challenge of diffusion effects. Our conclusions are limited by the large inter-core deviations and the low signal-to-noise ratio in the stack deuterium excess signal.

\subsection{Surface air temperature and relationship with $\delta^{18} \mathrm{O}$}

Here, we compare the NEEM $\delta^{18} \mathrm{O}$ with temperature data from the composite record of coastal stations (Vinther et al., 2006), the gridded reconstruction based on the interpolation of coastal and Greenland automatic weather station information (Box et al., 2009), and simulations performed with the different atmospheric models.
We first discuss the annual mean temperature. For the period 1958-2011, annual mean surface snow temperature is estimated at $-28.15 \pm 0.13{ }^{\circ} \mathrm{C}$ from the least-square inversion of NEEM borehole temperature measurements. The annual mean temperature estimate from PARCA AWS (automatic weather station) surface air temperature measurements, available for $2009-2011$, is $-26.8 \pm 1.8^{\circ} \mathrm{C}$. This range is consistent with the mean surface air temperature in the MAR simulation, as well as the temperature reconstruction updated from (Box et al., 2009), scaled against another regional model and independent of NEEM ice core data. However, the atmospheric general circulation models have warm biases (about $2{ }^{\circ} \mathrm{C}$ for ECHAM5-wiso-ERA at T106, $5^{\circ} \mathrm{C}$ for ECHAM5-wiso-ERA at T63 and up to $8^{\circ} \mathrm{C}$ for LMDZiso-20CR), consistent with the lack of depletion for the simulated $\delta^{18} \mathrm{O}$. While the NCEP nudging leads to an underestimation of variance, the observed variance is well captured using the ERA forcing for all models.

Before comparing the NEEM ice core records with the model outputs, we first compare the representation of annual mean precipitation $\delta^{18} \mathrm{O}$ and temperature in the LMDZisoERA and ECHAM5-wiso-ERA simulations. The model results are significantly correlated at the inter-annual scale from 1979 to 2007, with a correlation coefficient of 0.95 for surface air temperature and 0.83 for precipitation $\delta^{18} \mathrm{O}$. They however produce different trends and different results for specific warm/cold years. As a result, they simulate different relationships between $\delta^{18} \mathrm{O}$ and temperature. At the inter-annual scale, LMDZiso-ERA produces a slope of $0.5 \% 0^{\circ} \mathrm{C}^{-1}$, with a correlation coefficient of 0.59 ; ECHAM5-wiso-ERA produces a slope of $0.8 \% 0^{\circ} \mathrm{C}^{-1}$, with 
Table 6. Calculations of NEEM - $\delta^{18} \mathrm{O}$ temporal slope for the period 1979-2007 using all sources of information (six temperature estimates and three $\delta^{18} \mathrm{O}$ estimates). For each data source, the slope is calculated based on the ratio of the multidecadal trends for $\delta^{18} \mathrm{O}$ and for temperature. The reported statistics are the mean and standard deviation of trends and slopes calculated for all listed source data sets. Here, NEEM temperature reconstruction refers to the data set of Box et al. (2009).

\begin{tabular}{|c|c|c|c|}
\hline $\begin{array}{l}\text { Source } \\
\text { data }\end{array}$ & $\begin{array}{l}\text { Temperature trend } \\
\left({ }^{\circ} \mathrm{C} \text { decade }{ }^{-1}\right)\end{array}$ & $\begin{array}{l}\delta^{18} \mathrm{O} \text { trend } \\
\left(\% \text { o decade }{ }^{-1}\right)\end{array}$ & $\begin{array}{l}\text { Ratio } \\
\%{ }^{\circ} \mathrm{C}^{-1}\end{array}$ \\
\hline $\begin{array}{l}\text { NEEM } \delta^{18} \mathrm{O} \\
\text { annual mean SW } \\
\text { coastal temperature }\end{array}$ & $0.83 \pm 0.32$ & $0.77 \pm 0.25$ & 0.93 \\
\hline $\begin{array}{l}\text { NEEM } \delta^{18} \mathrm{O} \\
\text { NEEM temperature } \\
\text { reconstruction }\end{array}$ & $0.98 \pm 0.27$ & $0.77 \pm 0.25$ & 0.79 \\
\hline $\begin{array}{l}\text { NEEM } \delta^{18} \mathrm{O} \\
\text { NEEM borehole } \\
\text { temperature inversion }\end{array}$ & $0.96 \pm 0.02$ & $0.77 \pm 0.25$ & 0.80 \\
\hline $\begin{array}{l}\text { NEEM } \delta^{18} \mathrm{O} \\
\text { MARv3.4-ERA temperature }\end{array}$ & $0.58 \pm 0.22$ & $0.77 \pm 0.25$ & 1.33 \\
\hline $\begin{array}{l}\text { NEEM } \delta^{18} \mathrm{O} \\
\text { MARv3.4-NCEP temperature }\end{array}$ & $0.63 \pm 0.24$ & $0.77 \pm 0.25$ & 1.22 \\
\hline $\begin{array}{l}\text { NEEM } \delta^{18} \mathrm{O} \\
\text { MARv3.4-20CR temperature }\end{array}$ & $0.58 \pm 0.21$ & $0.77 \pm 0.25$ & 1.33 \\
\hline $\begin{array}{l}\text { NEEM } \delta^{18} \mathrm{O} \\
\text { LMDZiso-ERA temperature }\end{array}$ & $0.65 \pm 0.22$ & $0.77 \pm 0.25$ & 1.18 \\
\hline $\begin{array}{l}\text { NEEM } \delta^{18} \mathrm{O} \\
\text { ECHAM-5wiso-ERA temperature }\end{array}$ & $0.81 \pm 0.24$ & $0.77 \pm 0.25$ & 0.95 \\
\hline $\begin{array}{l}\text { LMDZiso-ERA } \delta^{18} \mathrm{O} \\
\text { and temperature }\end{array}$ & $0.65 \pm 0.22$ & $0.82 \pm 0.17$ & 1.26 \\
\hline $\begin{array}{l}\text { ECHAM5-wiso-ERA } \delta^{18} \mathrm{O} \\
\text { and temperature }\end{array}$ & $0.81 \pm 0.24$ & $0.69 \pm 0.18$ & 0.85 \\
\hline Statistics & $\begin{array}{l}0.74 \pm 0.14 \\
(n=10)\end{array}$ & $\begin{array}{l}0.76 \pm 0.07 \\
(n=3)\end{array}$ & $\begin{array}{l}1.05 \pm 0.23 \\
(n=10)\end{array}$ \\
\hline
\end{tabular}

a stronger correlation coefficient (0.79). These results are strongly constrained by the cold event of 1982-1983. When focusing on the multidecadal scale, the two models produce different amplitudes of temperature and $\delta^{18} \mathrm{O}$ trends (Table 6). ECHAM5-wiso-ERA produces a multidecadal slope of $0.85 \% 0^{\circ} \mathrm{C}^{-1}$, while LMDZiso-ERA produces a slope of $1.26 \% 0^{\circ} \mathrm{C}^{-1}$.

The inter-annual correlation coefficient between annual mean temperature and NEEM ice core $\delta^{18} \mathrm{O}$ (Table 5) is very weak for the LMDZiso-20CR simulation and varies from 0.31 to 0.49 for the ERA-nudged simulations with MAR, ECHAM5-wiso and LMDZiso. Such correlation strengths are comparable to those obtained within each simulation, and comparable to those obtained between the NEEM ice core $\delta^{18} \mathrm{O}$ and the simulated $\delta^{18} \mathrm{O}$. For ECHAM5wiso and LMDZiso, we observe a stronger correlation with precipitation-weighted temperatures (calculated from monthly outputs) than with annual mean temperature ( $R$ increases up to 0.67 in LMDZiso). This is not consistent with the recent finding that the isotopic composition of summer surface snow may record a continuous signal due to exchanges with the surface vapour isotopic composition, itself related to temperature, rather than a precipitation-weighted signal (Steen-Larsen et al., 2014).

Correlations calculated from the gridded reconstruction are comparable to those obtained using atmospheric model outputs ( 0.55 for the first reconstruction) and a loss of correlation prior to 1958 (down to 0.3-0.4). When considering SW Greenland instrumental temperature, the strength of the correlation with NEEM ice core $\delta^{18} \mathrm{O}$ depends on the season and is strongest in JJAS, as previously reported, where it reaches 0.42 for $1958-2011$. Surprisingly, the correlation with DJFM 
Table 7. Calculations of NEEM accumulation-surface-airtemperature relationship for the period 1979-2007 using all sources of information.

\begin{tabular}{ll}
\hline Source data & $\begin{array}{l}\text { Accumulation- } \\
\text { temperature } \\
\text { relationship } \%{ }^{\circ} \mathrm{C}^{-1}\end{array}$ \\
\hline $\begin{array}{l}\text { NEEM accumulation } \\
\text { Annual mean SW coastal temperature }\end{array}$ & 9.5 \\
\hline $\begin{array}{l}\text { NEEM accumulation } \\
\text { NEEM temperature reconstruction }\end{array}$ & 8.1 \\
\hline $\begin{array}{l}\text { NEEM accumulation } \\
\text { NEEM borehole temperature inversion }\end{array}$ & 8.2 \\
\hline $\begin{array}{l}\text { NEEM accumulation } \\
\text { MARv3.4-ERA temperature }\end{array}$ & 13.6 \\
\hline $\begin{array}{l}\text { NEEM accumulation } \\
\text { MARv3.4-NCEP temperature }\end{array}$ & 12.6 \\
\hline $\begin{array}{l}\text { NEEM accumulation } \\
\text { MARv3.4-20CR temperature }\end{array}$ & 13.6 \\
\hline $\begin{array}{l}\text { NEEM accumulation } \\
\text { LMDZiso-ERA temperature }\end{array}$ & 12.2 \\
\hline $\begin{array}{l}\text { NEEM accumulation } \\
\text { ECHAM-5wiso-ERA temperature } \\
\text { and temperature }\end{array}$ & 10.8 \\
\hline $\begin{array}{l}\text { MARv3.4-ERA precipitation } \\
\text { and temperature }\end{array}$ & 15.9 \\
\hline $\begin{array}{l}\text { and temperature } \\
\text { and temperature }\end{array}$ & \\
\hline
\end{tabular}

temperature reported for the whole common time span (back to 1780) has vanished during the most recent decades, suggesting a decoupling between the drivers of winter coastal surface air temperature and ice sheet $\delta^{18} \mathrm{O}$, possibly associated with the impacts of coastal sea ice retreat near meteorological stations.

During the recent period (1979 to 2007), all the temperature data from reconstructions and simulations depict an increasing trend (Table 5), with a magnitude ranging from $0.58{ }^{\circ} \mathrm{C}$ per decade (MAR) to $0.81{ }^{\circ} \mathrm{C}$ (ECHAM5-wisoERA) and up to $0.98^{\circ} \mathrm{C}$ using the updated gridded reconstruction (Box et al., 2009). The high end is consistent with the temperature trend inferred from the NEEM borehole tem-

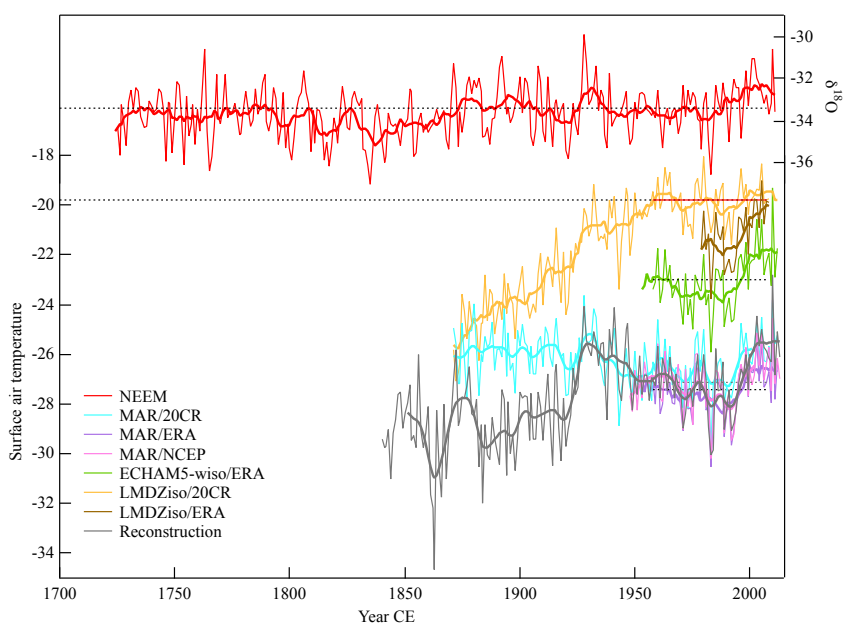

Figure 11. Comparison of NEEM $\delta^{18} \mathrm{O}$ (red, in \%o) with gridded temperature reconstructions and simulations (in ${ }^{\circ} \mathrm{C}$ ).

perature profile using 1000 Monte Carlo type simulations, estimated at $0.96 \pm 0.02^{\circ} \mathrm{C}$ per decade (1979-2011). For SW coastal Greenland instrumental temperature, the warming is stronger in winter $\left(0.95^{\circ} \mathrm{C}\right.$ per decade $)$ than in summer $\left(0.61{ }^{\circ} \mathrm{C}\right.$ per decade). This may arise from associated changes in local sea ice cover.

Greenland warming since 1979 is strongly driven by changes in large-scale atmospheric circulation (Fettweis et al., 2013a; Hanna et al., 2013, 2014), possibly arising from internal variability (Ding et al., 2014). We now take advantage of this recent increase in both $\delta^{18} \mathrm{O}$ and temperature to estimate a multidecadal temporal $\delta^{18} \mathrm{O}$-temperature relationship at NEEM. For this purpose, we can calculate this slope from LMDZiso-ERA and ECHAM5-wiso-ERA simulations, based on multidecadal trends in each parameter; we can also calculate the slope using NEEM $\delta^{18} \mathrm{O}$ and all reconstructions and simulations for the magnitude of the temperature trend (Fig. 11, Table 6). The resulting ranges of slopes converge within $1.05 \pm 0.2 \%{ }^{\circ} \mathrm{C}^{-1}$; this uncertainty does not account for the uncertainty associated with the estimation of each trend. From the longest temperature data set available from the MAR-20CR simulation and from the reconstruction, and the NEEM ice core $\delta^{18} \mathrm{O}$ data (not shown), it appears that the isotope-temperature relationship is not stable through time. When calculated over running 30 year periods, the inter-annual slope has an average value of $0.4 \pm 0.3 \% 0^{\circ} \mathrm{C}^{-1}(R=0.32)$. It is strongly enhanced in the last decades as well as during the $1920 \mathrm{~s}$ (up to $0.8 \% 0^{\circ} \mathrm{C}^{-1}$ using the reconstruction and $1 \% 0^{\circ} \mathrm{C}^{-1}$ using MAR).

This slope is unusually strong, as it is even higher than spatial gradients in Greenland (Sjolte et al., 2011; MassonDelmotte et al., 2011) and higher than the large slope recently observed in surface water vapour at NEEM (SteenLarsen et al., 2014). Both the correlations with temperature and the magnitude of the slope are stronger than observed 


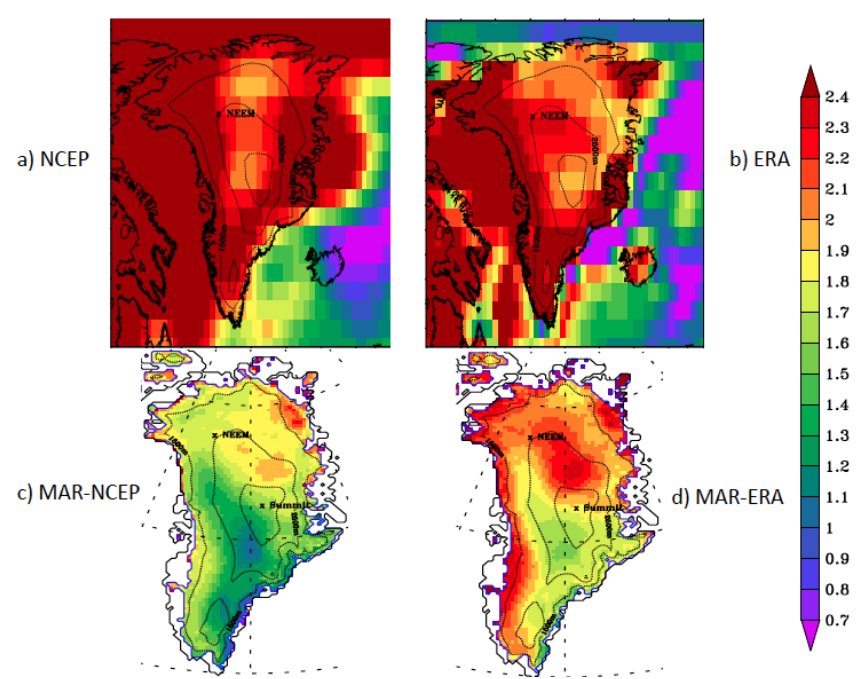

Figure 12. Map of surface air temperature change calculated from 1979 to 2011 (a) NCEP, (b) MAR-NCEP, (c) ERA-Interim, (d) MAR-ERA.

from vapour data in south Greenland (Bonne et al., 2014) and inter-annual variations during the last decades using long precipitation isotopic time series, e.g. in Europe (Rozanski et al., 1992) or Canada (Birks and Edwards, 2009), which usually show slopes of less than $0.5 \% 0^{\circ} \mathrm{C}^{-1}$. This suggests that specific amplifying processes are at play around NEEM, which increase the sensitivity of vapour and snowfall isotopic composition to local surface air temperature changes. The first potential candidate is the change in precipitation intermittency/seasonality. If the recent warming is associated with enhanced summer snowfall to the expense of winter snowfall, then this will also produce an enrichment of $\delta^{18} \mathrm{O}$. However, none of the atmospheric simulations exploited here depicts any significant trend in the fraction of summer to annual precipitation during 1979-2007. Another potential amplifier lies in the retreat of the sea ice cover in the Labrador Sea/Baffin Bay. A reduced sea ice cover may amplify regional temperature changes and favour enhanced storminess and enhanced precipitation (Noël, 2014), thus bringing more local moisture during summer. A stronger contribution from such nearby moisture sources is expected to enrich $\delta^{18} \mathrm{O}$, in contrast with long-distance transport of moisture from the North Atlantic, associated with strong distillation (Bonne et al., 2014, 2015). Water tagging simulations performed within highresolution atmospheric models could help to test the validity of this hypothesis. Indeed, sensitivity tests performed under warmer-than-present boundary conditions derived from climate projections show that Greenland $\delta^{18} \mathrm{O}$-temperature relationships are sensitive to patterns of nearby SST and sea ice changes (Sime et al., 2013). We suspect that differences in simulated moisture origin may also account for the $50 \%$ difference in the simulated temporal $\delta^{18} \mathrm{O}$-temperature relationship at NEEM in LMDZiso-ERA and ECHAM5-wiso-
ERA for 1979-2007, and for the model-data mismatch for deuterium excess.

\subsection{Relationship between surface air temperature and accumulation}

Using the temperature trends from 1979 to 2007 described in Table 6, and the accumulation trend from the NEEM ice core data or from the different models, we can also estimate the multidecadal relationship between surface air temperature and accumulation/precipitation (Table 7). It is reported in percentage of accumulation or precipitation increase per degree Celsius $\left({ }^{\circ} \mathrm{C}\right)$.

Large differences emerge within the different atmospheric simulations, with the lowest slope in ECHAM5wiso $\left(8.5 \%{ }^{\circ} \mathrm{C}^{-1}\right)$ and the highest one from MAR-ERA $\left(15.9 \%{ }^{\circ} \mathrm{C}^{-1}\right)$. When using the NEEM accumulation data with the three temperature time series inferred from observations (the coastal instrumental record, the gridded reconstruction and the borehole profile inversion), the estimated slope is $8.6 \pm 0.8 \%{ }^{\circ} \mathrm{C}^{-1}$. Larger values are systematically obtained when using temperature outputs from the atmospheric models. When considering all sources of information, we obtain a relationship of $11 \pm 3 \%{ }^{\circ} \mathrm{C}^{-1}$.

At NEEM, this estimated multidecadal accumulation sensitivity to temperature is significantly larger than expected from thermodynamical effects at the global scale for water vapour $\left(+7 \%{ }^{\circ} \mathrm{C}^{-1}\right)$ and than simulated by global climate models for precipitation at the global scale $\left(+3 \%{ }^{\circ} \mathrm{C}^{-1}\right)$ (IPCC, 2013). This implies that, at NEEM, accumulation sensitivity to temperature is driven by dynamical processes associated with storm track changes.

We therefore identify unusually strong responses of both $\delta^{18} \mathrm{O}$ and accumulation to the local temperature increase over the past decades. Further investigations of moisture transport changes are needed to explore the processes at play, such as changes in storm tracks associated with sea ice retreat in the Baffin Bay area.

\subsection{Implications of NEEM shallow ice core data for recent climate change}

Here, we discuss results obtained at NEEM in a broader Greenland context. First, we report the spatial patterns of Greenland surface warming. Second, we investigate the strength of extreme warm-wet years identified in our NEEM ice core records (1928 and 2010 temperature anomalies; 1933 accumulation anomaly) in other Greenland records. Third, we compare the cold-dry decades of 1815-1825 and 1836-1846 in different ice core records. Finally, we investigate the response to volcanic eruptions in the NEEM records. 

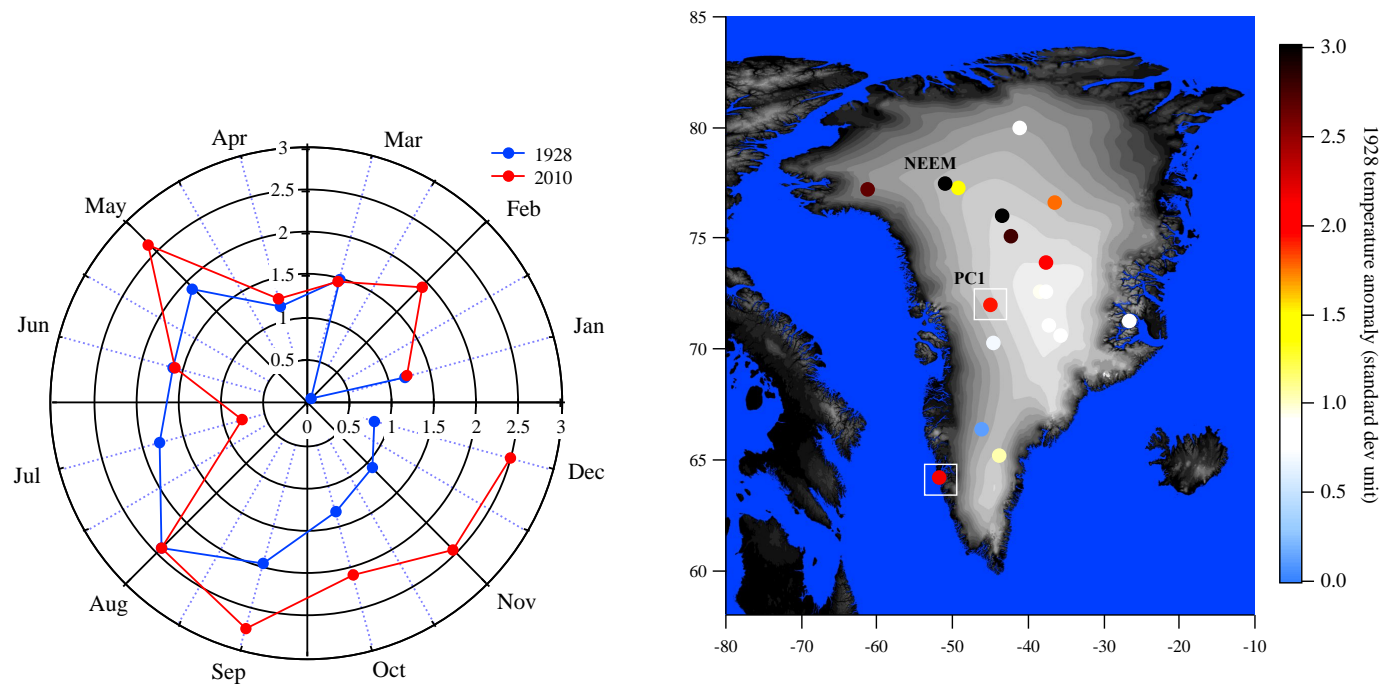

Figure 13. Temperature and $\delta^{18} \mathrm{O}$ anomalies during 1928. Left: comparison of seasonal temperature anomalies in 1928 and 2010. Polar graph showing the anomaly of SW Greenland temperature with respect to the average values of the earlier 30 years (1898-1927 and 1980-2009) in standard deviation units (scaled to the respective standard deviation of each 30-year interval), for 1928 (blue) and 2010 (red), as a function of the month (angle). The angle represents the month (anti-clockwise, from January to December); the distance to the disk centre represents standard deviation units (extreme monthly values will therefore be located on the outer part of the disk, with a radius above 1). Right: map showing the strength of the 1928 temperature and $\delta^{18} \mathrm{O}$ anomalies for SW coastal temperature (white rectangle), for the PC1 of Greenland $\delta^{18} \mathrm{O}$ (white rectangle labelled PC1) and for each ice core site, with respect to the average values in 1898-1927 and expressed in standard deviation units.

\subsubsection{Spatial patterns of recent Greenland surface warming}

In the previous section, we used different model results to provide estimates of recent temperature change at NEEM. Figure 12 compares the spatial pattern of annual mean Greenland warming directly from NCEP and ERA reanalyses, as well as MAR driven by these reanalyses, from 1979 to 2011. In reanalyses, very large surface warming trends are depicted in south, west and east Greenland $\left(+2.4^{\circ} \mathrm{C}\right)$. However, smaller trends are produced in places where meteorological data are assimilated (e.g. the south Greenland tip or Summit station), suggesting that reanalyses may overestimate the overall surface warming trend. Such caveats may arise from parameterisations of boundary layer processes and interactions between the atmosphere and the snow surface. Differences in the spatial pattern of warming are also noticeable, especially in northern Greenland.

By contrast, MAR simulates minimum warming in southeast and central Greenland, and maximum warming in the north and north-east sectors, together with the western coast in the MAR-ERA simulation. The MAR-ERA simulation produces stronger Greenland warming and a "warming hot spot" located in central north Greenland, reaching NEEM.

Evaluating the validity of these simulations (and the exact location of the warming hot spot) would require mapping recent warming using a network of automatic weather stations as well as ice core records (including accumulation, water-stable isotopes and borehole temperature profiles), for instance by updating measurements at earlier ice core sites. Implementing water-stable isotopes in MAR may also provide an independent validation tool.

\subsubsection{Characteristics of extreme warm-wet years: 2010, 1928 and 1933}

We now investigate the spatial structure of extreme events as recorded in Greenland, with a focus on 2010 and 1928 for temperature and $\delta^{18} \mathrm{O}$, and 1933 for accumulation. In order to have common metrics, the strength of each anomaly (calculated with respect to the average values for the earlier 30 years, considered as the background climate) is reported in standard deviation units, calculated for the preceding 3 decades. This approach allows us to make best use of existing data sets.

In NEEM $\delta^{18} \mathrm{O}, 2010$ scores 2.1 while 1928 scores 3.1 This differs from the SW Greenland temperature composite, where 2010 scores 2.8, as compared with 2.1 for 1928 . Only during July does 1928 have a stronger expression than 2010 in southern Greenland monthly temperature (Fig. 13, left panel). The fact that NEEM ice core $\delta^{18} \mathrm{O}$ records 1928 with the most enriched value is consistent with the known large fraction of snowfall deposited in summer at NEEM, leading to a summer bias in $\delta^{18} \mathrm{O}$. Alternatively, it is also possible that feedbacks acting above the ice sheet amplified summer warming during 1928 with respect to the tem- 

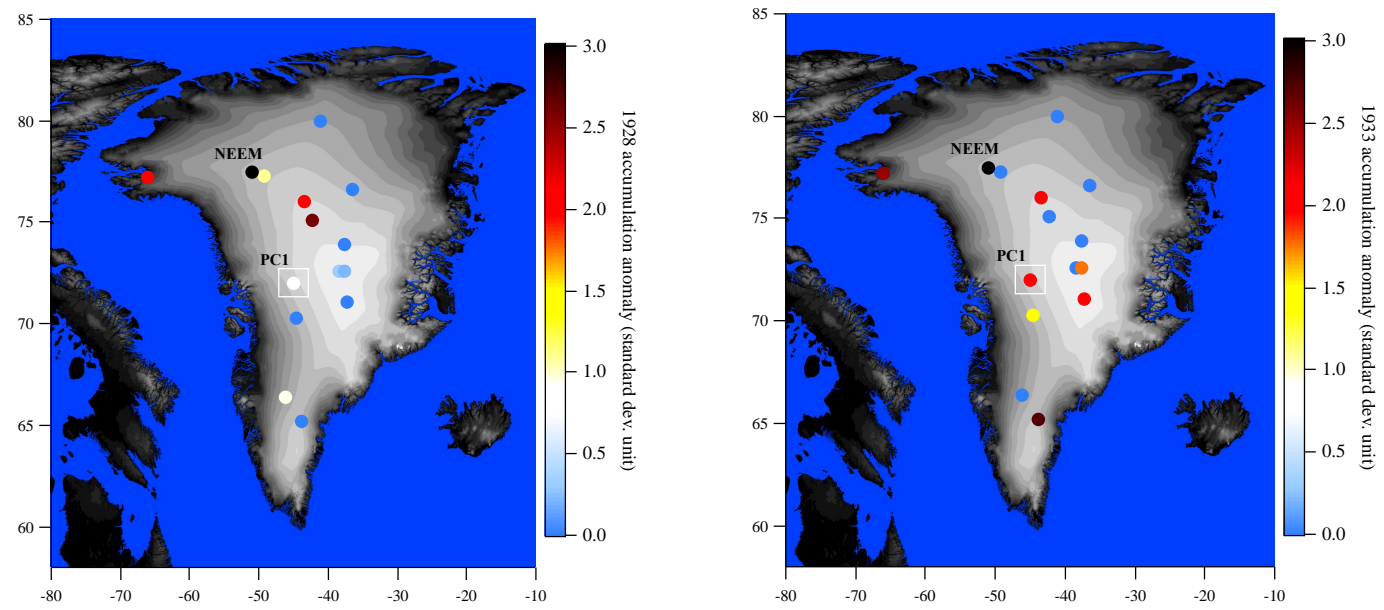

Figure 14. Accumulation anomalies during 1928 and 1933 with respect to the average values of 1898-1927, in standard deviation units (scaled to the standard deviation of accumulation in 1893-1927), for 1928 (left) and 1933 (right), as a function of the month (angle).
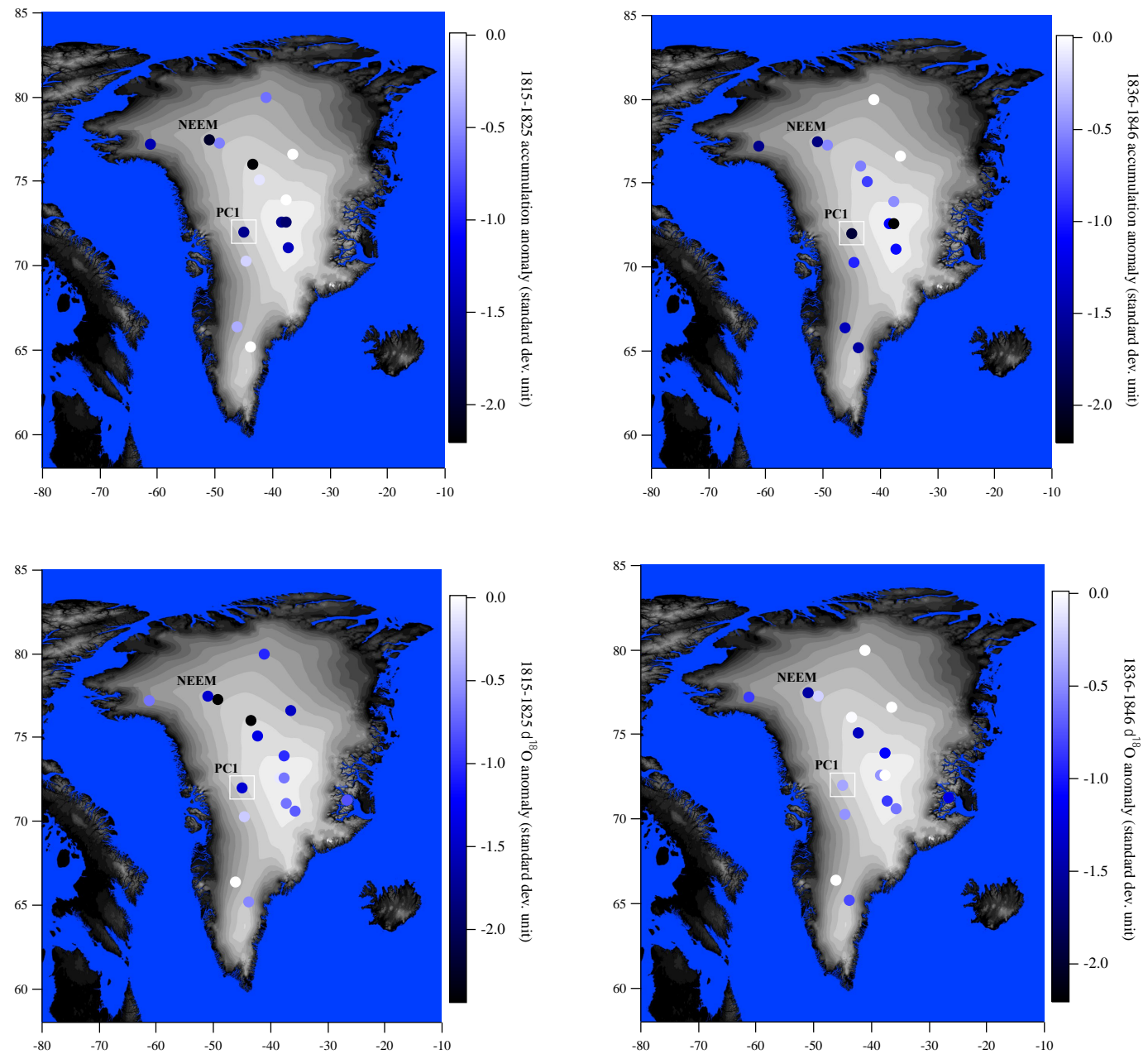

Figure 15. Map of accumulation (top) and $\delta^{18} \mathrm{O}$ (bottom) anomaly during 1815-1825 (left) and 1836-1846 (right) (corresponding respectively to the coldest-driest 11-year periods in PC1 and NEEM), calculated from individual records, as anomalies from the 1761-1966 average, and divided by the standard deviation of 11-year averages for 1761-1966 (in standard deviation units). 
perature anomaly which occurred at the coast, as observed during summer 2012 (Bennartz et al., 2013; Bonne et al., 2015). Such feedback mechanisms are not inconsistent with the spatial pattern of the 1928 anomaly (Fig. 13, right panel), which exhibits anomalous warming at the south-west Greenland coast and above the north-west ice sheet, with increasing strength from B16, Camp Century and north GRIP, and maximum strength at NEEM.

We then investigate similarly the spatial structure of accumulation anomalies recorded in 1928 (for comparison with the pattern of temperature and $\delta^{18} \mathrm{O}$ anomalies) and 1933 (when NEEM ice core data depict the wettest year) (Fig. 14). The strongest anomalies are in both cases identified at NEEM (respectively 4.3 and 4.9 standard deviation units). In 1928, accumulation anomalies above 2 standard deviations are only recorded in NW Greenland, consistent with the pattern of $\delta^{18} \mathrm{O}$ anomalies. This contrasts with more widespread accumulation anomalies identified in 1933 from south to northwest Greenland. As a result, the strength of the 1933 anomaly is about twice as strong in the accumulation PC1 as the strength of the 1928 accumulation anomaly.

During summer (JJAS) 1928, large-scale circulation is marked by increased occurrence of NAO (and a negative summer NAO index) and a very large decrease in the occurrence of the Scandinavian blocking regime; the AMO index is neutral. By contrast, 1933 is characterised by a decreased occurrence of NAO weather regimes (and a positive summer NAO index), an increased occurrence of Scandinavian blocking, warm North Atlantic SST (positive AMO) and the second-most-active Atlantic hurricane season on record (from May to November) (Landsea, 2007). None of these large-scale modes show exceptional variability during these two periods.

This suggests that processes other than large-scale North Atlantic weather regimes are at play in driving these NW Greenland extreme years, as also observed during summer 2012 (Bonne et al., 2015).

\subsubsection{Characteristics of extreme cold-dry decades: 1815-1825 and 1836-1846}

We now compare the two coldest and driest 11-year intervals of the 19th century, as depicted by NEEM and PC1 $\delta^{18} \mathrm{O}$ and accumulation records (Fig. 15). The strength of decadal anomalies is again calculated from 1761-1966 mean values and standardised against the corresponding standard deviation of running 11-year averages. For accumulation, NEEM depicts the strongest anomaly in 1815-1825 (NEEM score: -2.0; PC1 score: -1.6), while accumulation PC1 has the strongest anomaly in 1836-1846 (PC1 score: -2.0; NEEM score: -1.7$)$. During the first period, the driest conditions are encountered along the NW Greenland ice divide (from Camp Century to NEEM, NGRIP, Summit and Crete). During the second period, there is a much more homogeneous pattern, depicting dry conditions above all of Greenland with the exception of the NE sector; the driest conditions are observed at Summit and NEEM. For $\delta^{18} \mathrm{O}$, NEEM shows a slightly stronger anomaly in $1836-1846$ (score -1.5 ) than in 1815-1825 (score -1.4); this also contrasts with $\delta^{18} \mathrm{O}$ PC1, which captures a similar strength of anomaly in 18151825 (score -1.5 ) but no exceptional anomaly in 1836 1846 (score -0.4). In 1815-1825, the spatial structure of $\delta^{18} \mathrm{O}$ anomalies shows widespread Greenland cooling, with increasing magnitude northwards, maximum at NGRIP and NEEM. In 1836-1846, the spatial structure is more heterogeneous, and the strongest $\delta^{18} \mathrm{O}$ anomalies are encountered along a NW-SE central Greenland transect (from NEEM to Renland). This comparison shows contrasted magnitudes and spatial coherency of anomalies in 1815-1825 (strong and widespread anomaly in $\delta^{18} \mathrm{O}$ ) and 1836-1846 (strong and widespread anomaly in accumulation). It would be very interesting to have such spatial information on deuterium excess anomalies, which could help to detect changes in moisture origin.

Unfortunately, it is not yet possible to compare the instrumental NAO changes in-between these two decades, due to the length of this record. The mean NAO index is positive in 1836-1846 in DJFM (index of 0.3), and negative in JJAS (index of -0.40). The proxy-based AMO reconstruction depicts a strong decrease of North Atlantic SST from 18151825 (AMO index of -0.13) to 1836-1846 (index of -0.64). The 1836-1846 period is characterised by the most negative 11-year-average anomalies in summer NAO, and the most negative 11-year-average anomalies in the historical AMO reconstruction.

The combination of strong negative anomalies in summer NAO and north Atlantic SST (through AMO) therefore seem to play a key role in driving remarkably cold and dry decades at NEEM, which reflect widespread anomalies in Greenland.

\subsubsection{Fingerprint of volcanic forcing}

Here, we have simply investigated the response of NEEM $\delta^{18} \mathrm{O}$, accumulation and deuterium excess following nine main volcanic eruptions of that period (in 1809, 1815, 1823, 1831, 1835, 1884, 1903, 1963 and 1991). We observe (Fig. S2 in the Supplement) a systematic $\delta^{18} \mathrm{O}$ depletion (cooling) in the 1-6 years following eruptions, an equivocal response of accumulation with a weak decrease in the 1-4 years following eruptions and no significant response of deuterium excess. This rather long-lasting response may be related to regional responses such as changes in Baffin Bay sea ice cover, in addition to the known impact of volcanic forcing on NAO (Ortega et al., 2015) and North Atlantic bi-decadal variability (Swingedouw et al., 2015). The NEEM and other Greenland ice core records offer a benchmark against which the climate model response to volcanic forcing and their internal variability can be tested. Expanding the NEEM record to the last millennium is needed to further assess the robustness of the signals. 


\subsection{Implications for NEEM deep ice core interpretation}

If the strong isotope-temperature relationship observed for the last 30 years at NEEM (and also inferred for the 1920s) is valid for earlier warm periods, despite differences in climate forcings and boundary conditions (Masson-Delmotte et al., 2011; Sime et al., 2013), then one should use this regional isotope-temperature relationship for the interpretation of NEEM isotopic records. A comparison of borehole temperature records is needed to validate this hypothesis, for instance for the Early Holocene. It is however consistent with the isotope-temperature relationship inferred at NEEM from estimates of abrupt temperature changes during abrupt events of the last deglaciation and several Dansgaard-Oeschger events, and which is stronger than for other Greenland sites (Guillevic et al., 2013; Buizert et al., 2014). Processes underlying the amplification of the isotope-temperature relationship in the last few decades need to be better understood before we can apply it with confidence to earlier changes, caused by different forcings. The remainder of this section is thus speculative.

For the last interglacial period, the observed $\delta^{18} \mathrm{O}$ anomaly of $3.6 \%$ at NEEM deposition site would then translate into $3.6 \pm 0.7^{\circ} \mathrm{C}$ warming, instead of the estimate of $7.5 \pm 1.8^{\circ} \mathrm{C}$ (NEEM, 2013) that was obtained using the Greenland average Holocene isotope-temperature relationship (Vinther et al., 2009). Moreover, if the accumulation-isotope relationship extracted here from shallow ice cores also applies for past warm periods, the last interglacial $\delta^{18} \mathrm{O}$ anomaly of $3.6 \%$ at NEEM deposition site would also indicate an increase in annual mean accumulation by approximately onethird. There is no reason for the temperature-accumulation and isotope-accumulation relationships to remain constant through time. Indeed, due to the strong change in summer insolation during the last interglacial period, climate models simulate a strong increase in the fraction of summer to annual precipitation (Masson-Delmotte et al., 2011), which may modify relationships between annual mean temperature, $\delta^{18} \mathrm{O}$ and accumulation. $\delta^{15} \mathrm{~N}$ records from the NEEM ice core should be used to independently test the validity of these temperature and accumulation estimates using firn modelling.

These scenarios are important for driving ice sheet models, for the comparison between climate simulations and last interglacial ice core records, and for the assessment of the vulnerability of the Greenland ice sheet to given levels of regional warming. Indeed, ice sheet modelling experiments constrained by ice core data supporting the presence of ice in Greenland from the last interglacial period, and also limited ice thickness change at NEEM (IPCC, 2013), have suggested that Greenland contributed $1.4-4.3 \mathrm{~m}$ sea level equivalent to the global 5-10 m sea level rise of the last interglacial period. This finding, combined with the initial estimate of temperature change at NEEM, implied that such a Greenland retreat was concurrent with a multi-millennial $8^{\circ} \mathrm{C}$ warming.
Such great warming was however not captured by state-ofthe-art climate models in response to orbital forcing (Capron et al., 2014). Limited ice sheet response with very large local warming is also difficult to reconcile with ice sheet simulations (IPCC, 2013). A $4{ }^{\circ} \mathrm{C}$ warming amplitude, as suggested by our study, would reduce model-data mismatches and has implications on the vulnerability of the Greenland ice sheet to regional warming.

Another implication of this study will be for the climatic interpretation of the Holocene NEEM accumulation and $\delta^{18} \mathrm{O}$ records. We have stressed the sensitivity of NEEM records to changes in temperature, as well as the imprint of summer NAO and, at the multidecadal scale, the imprint of AMO.

\section{Conclusions and perspectives}

We have produced and described a reference north-west Greenland stack record for $\delta^{18} \mathrm{O}$ and accumulation. At NEEM, these data sets show a strong sensitivity to local and Greenland temperature, as well as to North Atlantic subpolar gyre SST. Different patterns emerge from changes in $\delta^{18} \mathrm{O}$ and accumulation with respect to recent trends, extreme cold (warm) and dry (wet) years. NEEM shallow ice core records are affected by changes in atmospheric circulation, but with weaker relationships with winter NAO than in central or southern Greenland; we confirm the impact of the Atlantic Ridge and Greenland blocking weather regimes in north-west Greenland.

NEEM climate variability is marked by a large multidecadal variability, which is closely related to the Atlantic Multidecadal Oscillation indices and enhanced at the beginning of the 19th century. We report extreme cold and dry decades of the 19th century depicted in NEEM ice cores. Our ice core record could be further compared with historical sources, such as diaries from the British and Danish Royal Navy officers who explored the east and west Greenland coasts in the 1820s-1830s. For instance, Captain Graah qualitatively describes an extremely cold and dry winter in 1829-1830, following the persistence of sea ice along southwest Greenland during summer 1829 (Graah, 2014). In parallel, quantitative oceanographic and meteorological measurements were performed by Captain John Ross along west Greenland, during the same period (Ross and Ross, 1835). The mechanisms responsible for these cold and dry decades may involve the impact of repeated volcanic eruptions on the North Atlantic SST and the Labrador Sea/Baffin Bay sea ice extent, and they should motivate further investigations using historical climate simulations.

Progress is required on the accuracy of deuterium excess measurements using laser instruments, and in the number of initial source records to be stacked, in order to extract a robust signal from the analytical and inter-core noise. We note a hint for large-scale atmospheric circulation control on deu- 
terium excess from the relationship observed with the North Atlantic SST and some similarity between our record and the ECHAM5-wiso-ERA simulation.

Our model-data comparison stresses a generally better performance from simulations nudged to ERA reanalysis when compared to the simulations nudged to NCEP and 20CR reanalyses. The MAR-20CR-simulated temperature and accumulation show reasonable skill prior to 1930 with respect to the NEEM shallow ice core data, with correlation coefficients above $R=0.4$ (1871-1930). This motivates an ongoing effort to implement water-stable isotopes in the MAR model for direct comparison with ice core records.

If we focus on the recent warming (1979-2007), the biases of atmospheric general circulation model results for mean precipitation amounts at the NEEM site affect the magnitude of their simulated inter-annual variability and precipitation trends. The large increase in temperature inferred from borehole data and gridded temperature reconstructions is captured by all atmospheric models, as well as the large increase in $\delta^{18}$ O. However, LMDZiso-ERA and ECHAM5wiso-ERA simulate a decrease in deuterium excess, which is not detected in the NEEM shallow ice core records.

Combining observations and simulations of local $\delta^{18} \mathrm{O}$ and temperature, we focused on the isotope-temperature relationship emerging during the most recent period, where warming reaches levels above pre-industrial conditions and where a global warming signal is present in Greenland, in addition to the impact of changes in atmospheric circulation (Fettweis et al., 2013a; Hanna et al., 2014). During the period 1979-2007, we observe a very strong dependency of NEEM $\delta^{18} \mathrm{O}$ to local temperature at the multidecadal scale, with a slope twice as large as that inferred from Holocene variations in other Greenland ice cores (Vinther et al., 2009). We also report a high sensitivity of NEEM accumulation to temperature. Further work is needed to understand the amplifying mechanisms at play and their potential validity for earlier warm periods caused by other mechanisms (such as the climate response to orbital forcing for the last interglacial period). Similarly, the decoupling of changes in accumulation and $\delta^{18} \mathrm{O}$, which emerges from the shallow ice core data (especially for 1979-2007), may have implications for the interpretation of ice core data. If applicable to earlier periods of North Atlantic warming and Arctic sea ice retreat, these findings have implications for the interpretation of NEEM ice core data for past warm episodes (e.g. early Holocene and last interglacial period).

\section{The Supplement related to this article is available online} at doi:10.5194/tc-9-1481-2015-supplement.
Acknowledgements. NEEM is directed and organised by the Centre for Ice and Climate at the Niels Bohr Institute and US NSF, Office of Polar Programs. It is supported by funding agencies and institutions in Belgium (FNRS-CFB and FWO), Canada (NRCan/GSC), China (CAS), Denmark (FIST), France (IPEV, CNRS/INSU, CEA and ANR), Germany (AWI), Iceland (RannIs), Japan (NIPR), Korea (KOPRI), the Netherlands (NWO/ALW), Sweden (VR), Switzerland (SNF), the United Kingdom (NERC) and the USA (US NSF, Office of Polar Programs). This study has been funded by the ANR CEPS GREENLAND project (ANR-10-CEPS-0008). This is Past4Future contribution no. xx. The research leading to these results has received funding from the European Union's Seventh Framework Programme (FP7/2007-2013) under grant agreement no. 243908, "Past4Future. Climate change - Learning from the past climate". We thank Suzanne Buchardt for providing us with estimates of the accumulation- $\delta^{18} \mathrm{O}$ relationship derived from the chronology of the NEEM deep ice core. We finally acknowledge support by the Danish Council for Independent Research - Natural Sciences grant 10-092850 and the AXA Research Fund. This is LSCE publication 5522.

Edited by: E. Hanna

\section{References}

Andersen, K. K., Ditlevsen, P. D., Rasmussen, S. O., Clausen, H. B., Vinther, B. M., Johnsen, S. J., and Steffensen, J. P.: Retrieving a common accumulation record from greenland ice cores for the past 1800 years, J. Geophys. Res.-Atmos., 111, D15106, doi:10.1029/2005jd006765, 2006.

Bennartz, R., Shupe, M. D., Turner, D. D., Walden, V. P., Steffen, K., Cox, C. J., Kulie, M. S., Miller, N. B., and Pettersen, C.: July 2012 greenland melt extent enhanced by low-level liquid clouds, Nature, 496, 83-86, 2013.

Birks, S. J. and Edwards, T. W. D.: Atmospheric circulation controls on precipitation isotope-climate relations in western canada, Tellus B, 61, 566-576, doi:10.1111/j.1600-0889.2009.00423.x, 2009.

Bonne, J.-L., Masson-Delmotte, V., Cattani, O., Delmotte, M., Risi, C., Sodemann, H., and Steen-Larsen, H. C.: The isotopic composition of water vapour and precipitation in Ivittuut, southern Greenland, Atmos. Chem. Phys., 14, 4419-4439, doi:10.5194/acp-14-4419-2014, 2014.

Bonne, J., Steen-Larsen, H.-C., Clerbaux, C., Cesana, G., Delmotte, M., Fettweis, X., Lacour, J.-L., Masson-Delmotte, V., Risi, C., Sodemann, H., and Werner, M.: The summer 2012 greenland heat wave: In situ and remote sensing observations of water vapour isotopic composition along an atmospheric river event, J. Geophys. Res., 120, 2970-2989, 2015.

Box, J. E.: Greenland ice sheet mass balance reconstruction. Part ii, surface mass balance (1840-2010), J. Clim., 26, 6974-6989, 2013.

Box, J. E., Yang, L., Bromwhich, D., and Bai, L.-S.: Greenland ice sheet surface air temperature variability: 1840-2007, J. Climate, 22, 4029-4049, 2009.

Box, J. E., Cressie, N., Bromwich, D. H., Jung, J.-H., van den Broeke, M., van Angelen, J. H., Forster, R. R., Miège, C., Mosley-Thompson, E., Vinther, B., and McConnell, J. R.: 
Greenland ice sheet mass balance reconstruction. Part i: Net snow accumulation (1600-2009), J. Climate, 26, 3919-3934, doi:10.1175/jcli-d-12-00373.1, 2012.

Buchardt, S. L., Clausen, H. B., Vinther, B. M., and Dahl-Jensen, D.: Investigating the past and recent $\delta^{18} \mathrm{O}$-accumulation relationship seen in Greenland ice cores, Clim. Past, 8, 2053-2059, doi:10.5194/cp-8-2053-2012, 2012.

Buizert, C., Gkinis, V., Severinghaus, J. P., He, F., Lecavalier, B. S., Kindler, P., Leuenberger, M., Carlson, A. E., Vinther, B., Masson-Delmotte, V., White, J. W. C., Liu, Z., Otto-Bliesner, B., and Brook, E. J.: Greenland temperature response to climate forcing during the last deglaciation, Science, 345, 1177-1180, doi:10.1126/science.1254961, 2014.

Butzin, M., Werner, M., Masson-Delmotte, V., Risi, C., Frankenberg, C., Gribanov, K., Jouzel, J., and Zakharov, V. I.: Variations of oxygen-18 in West Siberian precipitation during the last 50 years, Atmos. Chem. Phys., 14, 5853-5869, doi:10.5194/acp-145853-2014, 2014.

Cappelen, J. and Vinther, B. M.: Sw greenland temperature data 1784-2013, DMI, Copenhagen, Technical Report 14-06, 2014.

Capron, E., Govin, A., Stone, E. J., Masson-Delmotte, V., Mulitza, S., Otto-Bliesner, B., Rasmussen, T. L., Sime, L. C., Waelbroeck, C., and Wolff, E. W.: Temporal and spatial structure of multi-millennial temperature changes at high latitudes during the last interglacial, Quat. Sci. Rev., 103, 116-133, doi:10.1016/j.quascirev.2014.08.018, 2014.

Casado, M., Ortega, P., Masson-Delmotte, V., Risi, C., Swingedouw, D., Daux, V., Genty, D., Maignan, F., Solomina, O., Vinther, B., Viovy, N., and Yiou, P.: Impact of precipitation intermittency on nao-temperature signals in proxy records, Clim. Past, 9, 871-886, doi:10.5194/cp-9-871-2013, 2013.

Chylek, P., Folland, C. K., Dijkstra, H. A., Lesins, G., and Dubey, M. K.: Ice-core data evidence for a prominent near 20 year time-scale of the atlantic multidecadal oscillation, Geophys. Res. Lett., 38, L13704, doi:10.1029/2011g1047501, 2011.

Compo, G. P., Whitaker, J. S., Sardeshmukh, P. D., Matsui, N., Allan, R. J., Yin, X., Gleason, B. E., Vose, R. S., Rutledge, G., Bessemoulin, P., Brönnimann, S., Brunet, M., Crouthamel, R. I., Grant, A. N., Groisman, P. Y., Jones, P. D., Kruk, M. C., Kruger, A. C., Marshall, G. J., Maugeri, M., Mok, H. Y., Nordli, Ø., Ross, T. F., Trigo, R. M., Wang, X. L., Woodruff, S. D., and Worley, S. J.: The twentieth century reanalysis project, Q. J. Roy. Meteorol. Soc., 137, 1-28, doi:10.1002/qj.776, 2011.

Cuffey, K. M. and Clow, G. D.: Temperature, accumulation, and elevation in central greenland through the last deglacial transition, J. Geophys. Res., 102, 26383-26396, 1997.

Dee, D. P., Uppala, S. M., Simmons, A. J., Berrisford, P., and al., e.: Theera-interim reanalysis: Configuration and performance of the data assimilation system, Q. J. Roy. Meteorol. Soc., 137, 553597, 2011.

Ding, Q., Wallace, J. M., Battisti, D. S., Steig, E. J., Gallant, A. J. E., Kim, H.-J., and Geng, L.: Tropical forcing of the recent rapid arctic warming in northeastern canada and greenland, Nature, 509, 209-212, 2014.

Drinkwater, K., Colbourne, E., Loeng, H., Sundby, S., and Kristiansen, T.: Comparison of the atmospheric forcing and oceanographic responses between the labrador sea and the norwegian and barents seas, Prog. Oceanogr., 114, 11-25, doi:10.1016/j.pocean.2013.03.007, 2013.
Enfield, D. B., Mestas-Nuñez, A. M., and Trimble, P. J.: The atlantic multidecadal oscillation and its relation to rainfall and river flows in the continental U.S., Geophys. Res. Lett., 28, 20772080, doi:10.1029/2000g1012745, 2001.

Fettweis, X., Tedesco, M., van den Broeke, M., and Ettema, J.: Melting trends over the greenland ice sheet (1958-2009) from spaceborne microwave data and regional climate models, The Cryosphere, 5, 359-375, doi:10.5194/tc-5-359-2011, 2011.

Fettweis, X., Hanna, E., Lang, C., Belleflamme, A., Erpicum, M., and Gallee, H.: Important role of the mid-tropospheric atmospheric circulation in the recent surface melt increase over the greenland ice sheet, The Cryosphere, 7, 241-248, doi:10.5194/tc-7-241-2013, $2013 \mathrm{a}$.

Fettweis, X., Franco, B., Tedesco, M., van Angelen, J. H., Lenaerts, J. T. M., van den Broeke, M. R., and Gallée, H.: Estimating the greenland ice sheet surface mass balance contribution to future sea level rise using the regional atmospheric climate model mar, The Cryosphere, 7, 469-489, doi:10.5194/tc-7-469-2013, 2013b.

Fisher, D. A., Reeh, N., and Clausen, H. B.: Stratigraphic noise in time series derived from ice cores, Ann. Glaciol., 7, 76-83, 1985.

Graah, M. A.: Narrative of an expedition to the east coast of greenland: Sent by order of the king of denmark, in search of the lost colonies, under the command of captain w.A. Graah of the danish royal navy, Cambridge library collection - polar exploration, Cambridge University Press, Cambridge, 224 pp., 2014.

Guillevic, M., Bazin, L., Landais, A., Kindler, P., Orsi, A., MassonDelmotte, V., Blunier, T., Buchardt, S. L., Capron, E., Leuenberger, M., Martinerie, P., Prie, F., and Vinther, B. M.: Spatial gradients of temperature, accumulation and delta $\delta^{18}$-ice in greenland over a series of dansgaard-oeschger events, Clim Past, 9, 1029-1051, doi:10.5194/cp-9-1029-2013, 2013.

Hanna, E. and Cappelen, J.: Recent cooling in coastal southern greenland and relation with the north atlantic oscillation, Geophys. Res. Lett., 30, 1132, doi:10.1029/2002g1015797, 2003.

Hanna, E., Jones, J. M., Cappelen, J., Mernild, S. H., Wood, L., Steffen, K., and Huybrechts, P.: The influence of north atlantic atmospheric and oceanic forcing effects on 1900-2010 greenland summer climate and ice melt/runoff, Int. J. Climatol., 33, 862880, doi:10.1002/joc.3475, 2013.

Hanna, E., Fettweis, X., Mernild, S. H., Cappelen, J., Ribergaard, M. H., Shuman, C. A., Steffen, K., Wood, L., and Mote, T. L.: Atmospheric and oceanic climate forcing of the exceptional greenland ice sheet surface melt in summer 2012, Int. J. Climatol., 34, 1022-1037, doi:10.1002/joc.3743, 2014.

Hoffmann, G., Jouzel, J., and Johnsen, S. J.: Last millenium deuterium excess record from central greenland over the last millennium: Hints of a north atlantic signal during the little ice age, J. Geophys. Res., 106, 14265-14274, 2001.

Hourdin, F., Musat, I., Bony, S., Braconnot, P., Codron, F., Dufresne, J.-L., Fairhead, L., Filiberti, M.-A., Friedlingstein, P., Grandpeix, J.-Y., Krinner, G., LeVan, P., Li, Z.-X., and Lott, F.: The lmdz4 general circulation model: Climate performance and sensitivity to parametrized physics with emphasis on tropical convection, Clim. Dynam., 27, 787-813, doi:10.1007/s00382006-0158-0, 2006.

IPCC: Climate change 2013: The physical science basis, contribution of working group $i$ to the fifth assessment report of the intergovernemental panel on climate change, edited by: Stocker, T. F., Qin, D., Plattner, G. K., Tignor, M., Allen, S. K., Boschung, J., 
Nauels, A., Xia, Y., Bex, V., and Midgley, P., Cambridge University Press, Cambridge, UK and New York, NY, USA, 1535 pp., 2013.

Johnsen, S. J.: Stable isotope homogeneisation of polar snow and ice, Isotopes and impurities in snow and ice. IAHS Publication, Proceedings of the Grenoble Symposium August/September 1975, 210-219, 1977.

Johnsen, S. J., Clausen, H. B., Cuffey, K. M., Hoffmann, G., Schwander, J., and Creyts, T.: Diffusion of stable isotopes in polar firn and ice: The isotope effect in firn diffusion, Phys Ice Core Rec., 159, 121-140, 2000.

Jones, P. D., Jonsson, T., and Wheeler, D.: Extension to the north atlantic oscillation using early instrumental pressure observations from gibraltar and south-west iceland, Int. J. Climatol., 17, 1433 1450, doi:10.1002/(sici)1097-0088(19971115)17:13<1433::aidjoc203>3.0.CO;2-p, 1997.

Jouzel, J., Alley, R. B., Cuffey, K. M., Dansgaard, W., Grootes, P., Hoffmann, G., Johnsen, S. J., Koster, R. D., Peel, D., Shuman, C. A., Stievenard, M., Stuiver, M., and White, J.: Validity of the temperature reconstruction from ice cores, J. Geophys. Res., 102, 26471-26487, 1997.

Kalnay, E., Kanamitsu, M., Kistler, R., Collins, W., Deaven, D., Gandin, L., Iredell, M., Saha, S., White, G., Woollen, J., Zhu, Y., Chelliah, M., Ebisuzaki, W., Higgins, W., Janowiak, J., Mo, K. C., Ropelewski, C., Wang, J., Leetmaa, A., Reynolds, R., Jenne, R., and Joseph, D.: The ncep/ncar 40-year reanalyses project, B. Am. Meteor. Soc., 77, 437-431, 1996.

Krinner, G. and Werner, M.: Impact of precipitation seasonality changes on isotopic signals in polar ice cores, Earth Planet. Sci. Lett., 216, 525-538, 2003.

Kurita, N.: Origin of arctic water vapor during the icegrowth season, Geophys. Res. Lett., 38, L02709, doi:10.1029/2010g1046064, 2011.

Landais, A., Steen-Larsen, H. C., Guillevic, M., MassonDelmotte, V., Vinther, B., and Winkler, R.: Triple isotopic composition of oxygen in surface snow and water vapor at neem (greenland), Geochim. Cosmochim. Ac., 77, 304-316, doi:10.1016/j.gca.2011.11.022, 2012.

Landsea, C.: Counting atlantic tropical cyclones back to 1900, EOS, 88, 197-208, 2007.

Masson-Delmotte, V., Landais, A., Stievenard, M., Cattani, O., Falourd, S., Jouzel, J., Johnsen, S., Jensen, D., Sveinsbjornsdottir, A., White, J., Popp, T., and Fischer, H.: Holocene climatic changes in greenland: Different deuterium excess signals at greenland ice core project (grip) and northgrip, J. Geophys. Res.-Atmos., 110, D14102, doi:10.1029/2004jd005575, 2005.

Masson-Delmotte, V., Braconnot, P., Hoffmann, G., Jouzel, J., Kageyama, M., Landais, A., Lejeune, Q., Risi, C., Sime, L., Sjolte, J., Swingedouw, D., and Vinther, B.: Sensitivity of interglacial Greenland temperature and $\delta^{18} \mathrm{O}$ : ice core data, orbital and increased $\mathrm{CO}_{2}$ climate simulations, Clim. Past, 7, 10411059, doi:10.5194/cp-7-1041-2011, 2011.

NEEM: Eemian interglacial reconstructed from a greenland folded ice core, Nature, 493, 489-494, doi:10.1038/nature11789, 2013.

Noël, B., Fettweis, X., van de Berg, W. J., van den Broeke, M. R., and Erpicum, M.: Sensitivity of Greenland Ice Sheet surface mass balance to perturbations in sea surface temperature and sea ice cover: a study with the regional climate model MAR, The Cryosphere, 8, 1871-1883, doi:10.5194/tc-8-1871-2014, 2014.
Ortega, P., Swingedouw, D., Masson-Delmotte, V., Risi, C., Vinther, B., Yiou, P., Vautard, R., and Yoshimura, K.: Characterizing atmospheric circulation signals in greenland ice cores: Insights from a weather regime approach, Clim. Dynam., 1-21, doi:10.1007/s00382-014-2074-z, 2014.

Ortega, P., Lehner, F., Swingedouw, D., Masson-Delmotte, V., Raible, C. C., Casado, M., and Yiou, P.: A model-tested North Atlantic Oscillation reconstruction for the past millennium, Nature, 523, 71-74, doi:10.1038/nature14518, 2015.

Persson, A., Langen, P. L., Ditlevsen, P., and Vinther, B. M.: The influence of precipitation weighting on interannual variability of stable water isotopes in greenland, J. Geophys. Res.-Atmos., 116, D20120, doi:10.1029/2010JD015517, 2011.

Rasmussen, S. O., Abbott, P. M., Blunier, T., Bourne, A. J., Brook, E., Buchardt, S. L., Buizert, C., Chappellaz, J., Clausen, H. B., Cook, E., Dahl-Jensen, D., Davies, S. M., Guillevic, M., Kipfstuhl, S., Laepple, T., Seierstad, I. K., Severinghaus, J. P., Steffensen, J. P., Stowasser, C., Svensson, A., Vallelonga, P., Vinther, B. M., Wilhelms, F., and Winstrup, M.: A first chronology for the North Greenland Eemian Ice Drilling (NEEM) ice core, Clim Past, 9, 2713-2730, doi:10.5194/cp-9-2713-2013, 2013.

Risi, C., Bony, S., Vimeux, F., and Jouzel, J.: Water stable isotopes in the $1 \mathrm{mdz} 4$ general circulation model: Model evaluation for present day and past climates and application to climatic interpretations in tropical isotopic records, J. Geophys. Res., 115, D12118, doi:10.1029/2009JD013255, 2010.

Ross, J. and Ross, J. C.: Narrative of a second voyage in search of a north-west passage, and of a residence in the arctic regions during the years 1829, 1830, 1831, 1832, 1833, A. W. Webster, London, 1835

Rozanski, K., L., A.-A., and Gonfiantini, R.: Relation between longterm trends of oxygen-18 isotope composition of precipitation and climate, Science, 258, 981-985, 1992.

Sime, L. C., Risi, C., Tindall, J. C., Sjolte, J., Wolff, E. W., MassonDelmotte, V., and Capron, E.: Warm climate isotopic simulations: What do we learn about interglacial signals in greenland ice cores?, Quat. Sci. Rev., 67, 59-80, 2013.

Sjolte, J., Hoffmann, G., Johnsen, S. J., Vinther, B. M., Masson-Delmotte, V., and Sturm, C.: Modeling the water isotopes in greenland precipitation 1959-2001 with the mesoscale model remo-iso, J Geophys Res-Atmos., 116, D18105, doi:10.1029/2010jd015287, 2011.

Steen-Larsen, H. C., Masson-Delmotte, V., Sjolte, J., Johnsen, S. J., Vinther, B. M., Breon, F. M., Clausen, H. B., Dahl-Jensen, D., Falourd, S., Fettweis, X., Gallee, H., Jouzel, J., Kageyama, M., Lerche, H., Minster, B., Picard, G., Punge, H. J., Risi, C., Salas, D., Schwander, J., Steffen, K., Sveinbjornsdottir, A. E., Svensson, A., and White, J.: Understanding the climatic signal in the water stable isotope records from the neem shallow firn/ice cores in northwest greenland, J. Geophys. Res.-Atmos., 116, D06108, doi:10.1029/2010jd014311, 2011.

Steen-Larsen, H. C., Johnsen, S. J., Masson-Delmotte, V., Stenni, B., Risi, C., Sodemann, H., Balslev-Clausen, D., Blunier, T., Dahl-Jensen, D., Ellehoj, M. D., Falourd, S., Grindsted, A., Gkinis, V., Jouzel, J., Popp, T., Sheldon, S., Simonsen, S. B., Sjolte, J., Steffensen, J. P., Sperlich, P., Sveinbjnorsdottir, A. E., Vinther, B. M., and White, J. W. C.: Continuous monitoring of summer surface water vapor isotopic composition above the greenland ice 
sheet, Atmos. Chem. Phys., 13, 4815-4828, doi:10.5194/acp-134815-2013, 2013.

Steen-Larsen, H. C., Masson-Delmotte, V., Hirabayashi, M., Winkler, R., Satow, K., Prié, F., Bayou, N., Brun, E., Cuffey, K. M., Dahl-Jensen, D., Dumont, M., Guillevic, M., Kipfstuhl, J., Landais, A., Popp, T., Risi, C., Steffen, K., Stenni, B., and Sveinbjörnsdottír, A.: What controls the isotopic composition of greenland surface snow?, Clim. Past, 10, 377-392, doi:10.5194/cp-10377-2014, 2014.

Svendsen, L., Hetzinger, S., Keenlyside, N., and Gao, Y.: Marine-based multiproxy reconstruction of atlantic multidecadal variability, Geophys. Res. Lett., 41, 1295-1300, doi:10.1002/2013GL059076, 2014.

Swingedouw, D., Ortega, P., Mignot, J., Guilyardi, E., MassonDelmotte, V., Butler, P. G., Khodri, M., and Seferian, R.: Bidecadal north atlantic ocean circulation variability controlled by timing of volcanic eruptions, Nature Comm., 6, 1-12, doi:10.1038/ncomms7545, 2015.

Trenberth, K. E. and Shea, D. J.: Atlantic hurricanes and natural variability in 2005, Geophys. Res. Lett., 33, L12704, doi:10.1029/2006g1026894, 2006.

Uppala, S. M., KÅllberg, P. W., Simmons, A. J., Andrae, U., Bechtold, V. D. C., Fiorino, M., Gibson, J. K., Haseler, J., Hernandez, A., Kelly, G. A., Li, X., Onogi, K., Saarinen, S., Sokka, N., Allan, R. P., Andersson, E., Arpe, K., Balmaseda, M. A., Beljaars, A. C. M., Berg, L. V. D., Bidlot, J., Bormann, N., Caires, S., Chevallier, F., Dethof, A., Dragosavac, M., Fisher, M., Fuentes, M., Hagemann, S., Hólm, E., Hoskins, B. J., Isaksen, L., Janssen, P. A. E. M., Jenne, R., McNally, A. P., Mahfouf, J. F., Morcrette, J. J., Rayner, N. A., Saunders, R. W., Simon, P., Sterl, A., Trenberth, K. E., Untch, A., Vasiljevic, D., Viterbo, P., and Woollen, J.: The era-40 re-analysis, Q. J. Roy. Meteorol. Soc., 131, 29613012, doi:10.1256/qj.04.176, 2005.
Vinther, B., Johnsen, S. J., Andersen, K. K., H. B. Clausen, and Hansen, A. W.: Nao signal recorded in the stable isotopes of greenland ice cores, Geophys. Res. Lett., 30, 1387-1390, 2003.

Vinther, B. M., Andersen, K. K., Jones, P. D., Briffa, K. R., and Cappelen, J.: Extending greenland temperature records into the late eighteenth century, century, J. Geophys. Res.-Atmos., 111, D11105, doi:10.1029/2005jd006810, 2006.

Vinther, B. M., Buchardt, S. L., Clausen, H. B., Dahl-Jensen, D., Johnsen, S. J., Fisher, D. A., Koerner, R. M., Raynaud, D., Lipenkov, V., Andersen, K. K., Blunier, T., Rasmussen, S. O., Steffensen, J. P., and Svensson, A. M.: Holocene thinning of the greenland ice sheet, Nature, 461, 385-388, doi:10.1038/nature08355, 2009.

Vinther, B. M., Jones, P., Briffa, K., Clausen, H., Andersen, K., Dahl-Jensen, D., and Johnsen, S.: Climatic signals in multiple highly resolved stable isotope records from greenland, Quat. Sci. Rev., 29, 522-538, 2010.

Werner, M., Langebroek, P. M., Carlsen, T., Herold, M., and Lohmann, G.: Stable water isotopes in the echam5 general circulation model: Toward high-resolution isotope modeling on a global scale, J. Geophys. Res.-Atmos., 116, D15109, doi:10.1029/2011jd015681, 2011.

White, J. W. C., Barlow, L. K., Fisher, D., Grootes, P., Jouzel, J., Johnsen, S. J., Stuiver, M., and Clausen, H.: The climate signal in the stable isotopes of snow from summit, greenland: Results of comparisons with modern climate observations, J. Geophys. Res.-Oceans, 102, 26425-26439, doi:10.1029/97jc00162, 1997.

Zhang, X., Sorteberg, A., Zhang, J., Gerdes, R., and Comiso, J. C.: Recent radical shifts of atmospheric circulations and rapid changes in arctic climate system, Geophys. Res. Lett., 35, L22701, doi:10.1029/2008g1035607, 2008. 